University of Zurich

Department of Economics

Working Paper Series

ISSN 1664-7041 (print)

ISSN 1664-705X (online)

Working Paper No. 380

\title{
Growing Like Germany: \\ Local Public Debt, Local Banks, Low Private Investment
}

Mathias Hoffmann, Iryna Stewen and Michael Stiefel

Revised version, July 2021 


\title{
Growing Like Germany: \\ Local Public Debt, Local Banks, Low Private Investment*
}

\author{
Mathias Hoffmann \\ University of Zurich
}

\author{
Iryna Stewen \\ JGU Mainz
}

\author{
Michael Stiefel ${ }^{\dagger}$ \\ University of Zurich
}

This version: July 2021

\begin{abstract}
Using a firm-bank panel of more than $1 \mathrm{~m}$ German firms over 2010-2016, we document that local public bank lending to municipalities crowds out private investment. Our results show how crowding out can happen in a developed economy characterized by low interest rates and fiscal austerity. Our mechanism relies on two structural features of Germany's banking landscape: First, the geographical segmentation of credit markets for small and medium firms (SME) which are dominated by local banks. Second, a special statutory mandate requiring local public banks to lend to municipalities. With yields on local government debt declining to all-time lows, local public banks tried to alleviate stress on their balance sheets by using their local market power to charge higher rates on their SME customers. This crowded out firm investment. Perversely, fiscal consolidation at the state and federal levels contributed to this effect by putting pressure on the budgets of municipal governments which increasingly borrowed from local public banks. Crowding out lowered aggregate private investment by around 30-40 bio euros per year (or 1 percent of GDP). Thus, we identify a novel channel through which low interest rates can adversely affect bank lending and firm performance. Our results also illustrate how segmented credit markets can amplify negative multiplier effects from fiscal austerity.
\end{abstract}

KEYwords: local public finance, firm-level investment, crowding-out, fiscal austerity, global and intraEuropean imbalances

JEL-CODEs: E22, E40, E62, G21, G28 F21, F32, H32

\footnotetext{
${ }^{*}$ We thank Thomas Drechsel, Ippei Fujiwara, Takeo Hoshi, Pia Jankowski and her colleagues at DSGV, Steven Ongena, Marco Pagano, Isabel Schnabel, Gianluca Violante, and seminar participants at the KIT Karlsuhe, the DIW Berlin, the AlpMacro Workshop, the University of Tokyo, the Bank of Japan, Osaka University, Keio University, University of Zurich, the EEA 2020 annual meeting, University of Giessen, and the CEPR International Macro and Finance meeting for discussions and comments. Roxane Spitznagel, Claudine Schwarzenbach and Jan Petersohn provided excellent research assistance.

${ }^{\dagger}$ Mathias Hoffmann is Professor at the Department of Economics, University of Zurich. He is also affiliated with University of Zurich's Research Priority Program in Financial Market Regulation (URPP FinReg), the CESifo Munich and the Centre for Applied Macroeconomic Analysis (CAMA). E-mail: mathias.hoffmann@uzh.ch.

Iryna Stewen is Assistant Professor at Gutenberg School of Management and Economics, Johannes Gutenberg University Mainz, JakobWelder-Weg 4, D-55128 Mainz, Germany. She is also a CEPR research affiliate and an affiliate researcher at the URPP FinReg. E-mail: iryna.stewen@uni-mainz.de A previous version of this paper was part of Michael Stiefel's PhD thesis at the University of Zurich. He is grateful for a scholarship by the UBS Center of Economics in Society during his graduate studies. E-mail: michaelstiefel@outlook.com
} 


\section{Introduction}

Germany's exceptional growth over the last decade was accompanied by declining private investment. Low private investment also contributed to the country's high current account surplus that is widely perceived as an important source of intra-European and even global imbalances and has therefore moved into the focus of international policy-makers. ${ }^{1}$ In this paper, we draw attention to two important explanatory factors for Germany's low private investment rate that, so far, have not been explored in the context of advanced economies: the local segmentation of credit markets and the role of local public banks in local public finance.

Local public banks dominate lending to small and medium firms (SME) in Germany and, at the same time, also have an explicit mandate to lend to the local public sector (municipalities). As interest rates (and intermediation spreads) on municipal debt declined after the global financial crisis, this mandate effectively tied up a considerable part of local public banks' balance sheet in activities with practically zero margin. This put stress on the balance sheet of local public banks that they tried to alleviate by charging higher interest rates to their SME customers. Since SMEs could not easily switch lender in geographically segmented lending markets, they invested less. We estimate that this form of 'local crowding out' lowered aggregate private investment in Germany by around 30-40 billion euros per year (or 1 percent of GDP).

Perversely, fiscal consolidation at the state and federal levels substantially contributed to crowding out. It led to additional pressure on the (already strained) budgets of many municipal governments which were forced to plug the gaps by increased borrowing from local public banks. We use exogenous variation in the statelevel fiscal consolidation needs stipulated by the constitutional debt brake as instrument for local public banks' holdings of municipal debt. These results show that Germany's fiscal austerity over the last decade can account for three quarters of the crowding out of private investment in our sample.

While local crowding out, i.e. the notion of crowding out in locally segmented credit markets, has recently been prominently documented for a major emerging economy, China (Huang et al. (2020)), our results provide important first evidence on local crowding out for an advanced economy. Importantly, they show how such crowding out can take place in a low-interest rate environment. At a more general level, we therefore also identify a novel mechanism through which low interest rates can have adverse effects on real economic activity. Our findings also illustrate how the negative multiplier effects from fiscal austerity at higher (federal and state) level of government can be exacerbated in imperfect and segmented credit markets.

Germany's local banks come in two forms: local public banks (the 'Sparkassen' or savings banks) and lo-

\footnotetext{
${ }^{1}$ The European Commission has repeatedly criticized the macroeconomic imbalances in Germany, see for example European Commission (2019). On May 30th, 2017, US president Donald Trump tweeted: "We have a MASSIVE trade deficit with Germany. (...) Very bad for U.S. This will change" (Trump, 2017).
} 
cal cooperative banks (the Volksbanken). Together, they dominate local banking markets in large parts of the country. They have designated geographical areas of business in which other banks of the same type (savings or cooperative) are not allowed to compete. This institutional backdrop-the so-called "Regionalprinzip" (regional principle)—implies that German banking markets are segmented along regional or municipal boundaries. Their dense branch network gives local banks a very strong presence in local markets that the big nationwide banks (mainly Deutsche Bank with its Postbank subsidiary and Commerzbank) cannot match. In Germany, only 29\% of credit to firms and households stem from private banks, a comparatively low value (Gilquin, 2014).

The local segmentation of Germany's banking markets is particularly strong in lending to small and medium enterprises (SME). Many small German firms have long-standing relations with their local banks which are often their only bank connections. This relationship-based model is widely praised and the local banks pride themselves of it in their own publicity. Arguably, it allows the bank to screen borrowers much more closely and to continue lending to distressed firms even when arm's length lenders would long have stopped to provide credit. On the other hand, relationship lending also leads to a well-known hold-up problem (Sharpe, 1990): over the course of the relationship, the lender acquires private information about the borrower-and often holds the best collateral-which makes it hard for the borrowing firm to switch lender if the lender tightens loan terms.

While local cooperative and savings banks have a very similar clientele of private firms, the savings banks also play an important role in local public finance, including direct lending to municipalities and lending to local public enterprises. Differently from their local cooperative competitors, the savings banks have a statutory mandate to lend to the public sector. The savings banks are also under direct control of the municipalities in their respective district, with local mayors and other high-ranked officials being ex-officio members of their supervisory boards. This makes it hard for the savings banks to decline financing requests from the municipalities in their district. ${ }^{2}$

The local segmentation of Germany's banking markets and the role of savings banks for local public finance are long-standing institutional features of Germany's banking landscape. We argue that there are two related reasons that explain why these features have started to matter for crowding out over the last decade in particular. First, as the municipal spread-the difference between interest rates on municipal borrowing rates and deposit rates - has declined over the last decade, it has become less and less attractive for banks to lend to municipalities. However, savings banks' statutory public lending requirement did not allow them to reduce municipal loans

\footnotetext{
${ }^{2}$ Note that municipalities depend on banks for virtually all their borrowing. Municipal bonds play a minor role in German municipal finance and are usually only issued by major cities. For example, in 2010, the total debt of German municipalities vis-à-vis the private sector was around 123 billion euros of which only 0.175 billion were issued in the form of debt securities. See for example Table 2.1 in https://www.statistischebibliothek.de/mir/receive/DEHeft_mods_00009385
} 
by much. Low interest rates also made it difficult for deposit-dependent local public banks to attract additional funding. Therefore, the statutory public lending requirement created an increasing shadow cost on their balance sheets that they rolled over into increased interest rates for their least elastic private borrowers: SMEs who rely on relationship-based bank finance in locally segmented credit markets. The second reason-compounding the effect of low interest rates-was the deterioration of the fiscal situation of Germany's municipalities over the last decade. As we discuss below, this was caused by the consolidation of state- and federal budgets which happened at the expense of local municipalities. This created additional demand for municipal loans that local savings banks had to satisfy, thus exacerbating the crowding out of private-sector lending. ${ }^{3}$

To guide our empirical analysis, we propose a stylized theoretical model in the spirit of Brunnermeier and Koby (2019). In the model banks face constraints on lengthening their balance sheet in the form of imperfectly elastic deposit supply. In this setting, savings banks' statutory public lending constraint can become binding once municipal loan demand increases or if municipal borrowing rates decline. The binding statutory lending requirement induces a shadow cost that the bank seeks to make up for by increasing rates in the local market for private lending where it has market power. Consistent with this theory, we find that SME lending rates of local public banks increases significantly in the share of their lending to local governments and with falling public sector borrowing rates. This link is absent for the control group of local cooperative banks which do not have a statutory public lending mandate. Hence, savings banks charge their customers a spread over what comparable local cooperative banks charge their very similar customer firms. We refer to this spread as the break-even spread.

We then ask to what extent the break-even spreads charged by savings banks affect firm-level investment. Our firm-level analysis is based on a unique German firm-level panel that covers more than $1 \mathrm{~m}$ German firms over the period from 2010 until 2016, including many small ones not covered by other data sets. Our data also contains rich information on firms' bank relations that we use to construct a firm-specific measure of the break-even spreads charged by savings banks. We call this measure of exposure the firm's local public bank spread.

We argue that a firm's local public bank spread is exogenous to firm-specific characteristics because the individual break-even rates that enter it are computed using bank-level information only. Furthermore, because the firm-specific local bank spread exploits variation between firms and over time in firms' bank relations it is orthogonal to most conceivable confounding factors such as time-varying local- or sector-specific demand spillovers or unobserved firm or bank heterogeneity.

\footnotetext{
${ }^{3}$ This may raise the question why municipal spreads do not reflect the potential risks associated with lending to distressed municipalities. Under the Basel framework, loans to German municipalities have a risk weight of zero because local governments cannot declare bankruptcy under German law (their debt is legally guaranteed by the federal state).
} 
We show that the local public bank spread has a quantitatively important and significantly negative effect on firm level investment controlling for a host of firm-level variables and a rich set of controls for potential confounding factors. Specifically, our main specification controls for firm effects as well as for time-varying region-sector specific effects. This effectively accounts for compositional differences in the customer base of local banks. Hence, already in our baseline OLS estimates we can largely rule out that the effect of the local bank spread on investment arises because local banks in some areas lend to particularly small or risky firms or to some specifically risky sectors which would justify charging an interest rate spread even in the absence of our conjectured mechanism.

To fully account for any remaining reverse causality between firm investment and the financing conditions set by local public banks, in addition, we use a granular instrumental variable approach as recently proposed by Gabaix and Koijen (2020). This approach allows to purge local public bank spreads from unobserved factors that could be correlated with firm-level outcomes and that could affect different banks in a heterogeneous manner. Following Gabaix and Koijen (2020), we then construct an instrument from the granular residuals of this factor analysis. In this way we can fully dispel any concern that banks counterbalance particularly risky firm portfolios with high public lending shares or that risky, low-investment firms select to local public banks because no other banks would lend to them. These granular IV results confirm our earlier findings, both qualitatively and quantitatively.

We further buttress the causal interpretation of our findings by inspecting the transmission mechanism. First, we show that firms that face a higher local public bank spread see lower bank lending growth and pay slightly higher interest rates. Secondly, simple theory would suggest that crowding out is possible only if local demand for public borrowing can impact interest rates for other borrowers in the local economy. This requires local banking markets to be geographically segmented because otherwise borrowers could easily substitute local bank credit for alternative sources of finance. Consistent with this view, we document that our findings for investment, firm's bank borrowing and the average interest they pay are particularly strong in areas with strong geographical segmentation in which local public banks account for a high share of bank-firm relations. In the same vein, our findings are stronger for firms that are arguably more dependent on bank credit and find it harder to switch lender: younger or smaller firms and firms with fewer bank connections or a lack of internal funds.

Finally, to confirm that our results are driven by the special role of Germany's savings banks in municipal finance, we re-run our analysis using a placebo-sample in which firms' exposures are calculated based on breakeven spreads imputed for our control group of local cooperative banks. Here, none of our previous results hold.

Our findings therefore suggest that local bank lending to the public sector crowds out private sector invest- 
ment. The effect is economically important: according to our estimates, an increase in the local bank spread by 100 bps lowers investment for the average firm in our sample by about 6 percent. While many of the firms in our sample are small, the effect on Germany's aggregate investment-and therefore on the current account balance-is still considerable. We find that over our sample period, aggregate investment would have been, on average, 30-40 billion Euro per year higher in the absence of crowding out. This amounts to roughly 1 percent of German GDP per year.

Over the last decade, Germany's federal states and the federal government have tightened their spending under the influence of the so-called debt brake. Introduced into the federal constitution and most individual state constitutions in 2010, the debt brake stipulates that the federal government should not run a structural deficit of more than $0.35 \%$ of GDP from 2016, whereas the federal states should not incur any structural deficit at all beginning in 2020 .

Against this backdrop of fiscal austerity, it may appear surprising that we find any evidence of crowding out in Germany at all. We argue that fiscal austerity at the state- and federal levels and the financial distress of many municipalities are actually two sides of the same coin. In the process of fiscal consolidation stipulated by the debt brake, the federal and state governments have shifted many expensive government tasks to the municipalities, whose debt is explicitly exempted from the debt brake. Since municipalities' ability to raise taxes is very limited, their fiscal situation worsened.

Germany's recent experience with fiscal austerity therefore also allows us to answer to what extent the debt brake and the consolidation of state and federal budgets at the expense of municipalities can account for the crowding out we see in firm-level data. To this end, we use the consolidation needs of state-level budgets imposed by the debt brake to gauge the fiscal pressure that states pass on to municipalities. We interact statelevel consolidation needs with a municipality's fiscal situation at the beginning of the sample to instrument for the share of public lending on savings banks' balance sheets. We then repeat our firm-level analysis based on local public banks spreads constructed from instrumented public lending shares. This analysis confirms our earlier results and suggests that the debt brake alone accounts for roughly three quarters of the crowding out of private investment that we observe over our sample period.

Our findings therefore document a new channel through which fiscal austerity—and notably debt brakescan have contractionary effects. We conjecture that our results could be relevant in other settings. Many countries with federal systems of government (including e.g. the United States) have two-chamber systems in which federal and state level have to agree on any measures for fiscal consolidation and many of these countries have debt brakes at the state or federal levels. In such settings, there will always be an incentive to shift the burden of fiscal adjustment to lower levels of government that do not have direct parliamentary representation. Our 
results suggest that this may lead to substantial crowding out if lower levels of government then finance their borrowing needs in locally segmented credit markets.

The paper is structured as follows. Section 2 takes a first look at the data and section 3 embeds our paper into the literature. Section 4 describes our bank- and firm-level data sets. It also introduces our theoretical and empirical framework and discusses identification. Section 5 presents our main firm-level results. In section 6, we discuss the impact of fiscal austerity at the state- and federal levels on municipal borrowing and crowding out. In section 7, we explore extensions and provide further robustness checks. Section 8 concludes.

\section{A first look at the data and the mechanism}

In this section we take a first look at the data to motivate the central elements of our mechanism.

One important motivation for our analysis is Germany's external surplus which has been rising considerably since the global financial crisis. Our argument is that Germany's current account surplus is partly the result of low private investment which, in turn, can be explained by local crowding out. Figure 1 plots Germany's current account balance and its composition in terms of sectoral net lending of households, non-financial and financial corporations and of the government. As is apparent, the country has been running increasing current account surpluses since the late 1990s. Turning to the composition of the current account surplus, we see that in the years before the financial crisis it is predominantly the shrinking deficit of the public sector that drives the surplus. However, net non-financial corporate lending soars during the global financial crisis and remains high thereafter. Interestingly, this is also the period when the net lending of the government sector turns positive (after temporarily turning negative during the financial crisis). In the following we argue that these developments are related. The consolidation of (federal and state-level) public finances led to a deterioration in the financial situation of local municipalities. This increased pressure on local savings banks to lend to municipalities, crowding out private investment in locally segmented credit markets. This contributed to the increase in corporate net saving that we observe in Figure 1.

Our mechanism crucially relies on the local segmentation of Germany's credit markets. The map in Figure 2 shows the county-level variation in the share of firms with a local bank relationship in our sample. While the figure reveals considerable regional variation, its predominantly dark colour suggest that in many areas local banks are the main-and often only-provider of credit to SMEs. This dominance of local banks in their respective markets is one of the key elements of the mechanism we highlight in this paper. Not only are many SMEs too small and too opaque to borrow from the bigger, nationwide banks which are arm's length lenders. The map suggest that in many areas local banks are actually the "only game in town". This leaves SMEs highly 
exposed to changes in funding conditions imposed by the local banks.

Figure 3 illustrates the role of savings banks in local public finance. It plots a municipality's debt level (relative to GDP) against the public lending share on local banks' balance sheet. There is a clear positive relation but it is present mainly for the savings banks not for the cooperative banks. There are several important conclusions from this figure. First, it illustrates that public sector lending by savings banks is essential to local municipalities and their connected enterprises. Secondly, it shows that there is considerable variation in the municipal lending shares of savings banks. Third, our mechanism requires that there is a certain rivalry between lending to SMEs and to municipalities. If local public banks could elastically accommodate any municipal demand for credit by lengthening their balance sheet, we would not see any crowding out. In fact, Germany's local banks are highly dependent on local deposits. The typical savings banks will not be able to fully refinance increased municipal borrowing by simply lengthening its balance sheet proportionally. Figure 3 supports this view. Increased borrowing by municipalities not only increases the amount of municipal lending by savings banks but also the share of this lending in savings banks' balance sheet.

Another important ingredient of our mechanisms is that the decline in public sector borrowing rates has made it less attractive for banks to lend to municipal borrowers. Figure 4 shows time series for the average municipal borrowing rate and the average deposit rate of German banks. The difference between these seriesto which we refer as the municipal spread-has fallen to virtually zero over the period since the global financial crisis.

This fall in the municipal spread has affected savings banks more than other banks because their statutes require them to engage in municipal lending. Given the length of the banks' balance sheet, this leads to a high shadow cost in terms of forgone lending to more lucrative borrowers. We argue that this shadow cost has induced public banks to try to break even by charging higher rates on their other customers. Figure 5 illustrates this point. It plots the average firm lending rates of local banks (cooperative and public) against municipal lending shares for selected years in our sample.

Consistent with our hypothesis that high levels of public lending adversely affect financing conditions for local SMEs, a higher public loan share is associated with a significantly higher average firm-lending rate for the public savings banks. Conversely, the cooperative banks — which have no statutory requirement to lend to the public sector-generally have much lower public loan shares than the savings banks and the correlation between the firm-lending rate and the public loan share is weak and not statistically significant. Note also that the slope of this relation for the savings banks is becoming steeper over time, as we would expect-declining municipal lending rates increase the opportunity cost of municipal lending for the local public banks, leading 
to higher lending rates for firms. ${ }^{4}$

\section{Contribution to the literature}

Our paper integrates and builds on several strands of literature. Foremost, we contribute to a nascent literature on local crowding out. Using Chinese city- and firm-level data, Huang et al. (2020) show that private firms in cities with high levels of local government debt have lower investment while state-owned firms do not. Like ours, the mechanism explored by Huang et al. (2020) relies on the local segmentation of credit markets. However, our analysis differs from and extends Huang et al. (2020) in several important dimensions. The first is the institutional setting. Ours is the first paper to provide firm-level evidence of local crowding out in the context of a developed economy. Secondly, our use of matched bank-firm data allows us to put the crowdingout mechanism under the microscope. Specifically, Huang et al. (2020) cannot answer the question if bank lending to local government crowds out firm-level lending directly by reducing credit to firms connected to a specific bank or if it does so through a general equilibrium effect in which increased credit demand by local governments leads to a general increase in interest rates in the local credit market. Our bank-firm-level analysis allows us to show that crowding out takes place directly on individual banks' balance sheet through a tightening of credit conditions for the bank's firm customers. In so doing, our approach to identification exploits the unique institutional setting of Germany's banking system. There are two types of local banks in Germany, local public banks (the 'Sparkassen' or savings banks) and the local cooperative banks ('Volksbanken). Both serve the same local markets and a very similar base of private customers and small businesses. However, local public banks face a statutory public lending requirement and are under direct political control of local and municipal governments, a constraint that local cooperative banks do not face. This makes the local cooperative banks and their customers an important control group that helps us greatly in identifying the causal effect of higher municipal lending on private investment.

The idea that some form of financial repression by governments can reduce private sector lending has recently been explored by Becker and Ivashina (2018) who show that banks' lending to their respective governments increased during the European sovereign debt crisis and that this led to reduction in corporate credit

\footnotetext{
${ }^{4}$ Contrasting the findings in Figure 5 for savings banks with those obtained for the cooperative banks already allows us to effectively rule out an alternative explanation for a positive correlation between banks' municipal lending share and the average firm-lending rate: that local public banks in regions where SME lending is riskier (which would be associated with higher firm-lending rates) offset the impact of this risk on their balance sheets with higher public loan shares. Cooperative banks and savings banks have a very similar customer base of borrowers and are generally active in the same local markets. It is therefore implausible that the savings banks generally have riskier loan portfolios than their cooperative counterparts and that they should display a stronger tendency than cooperative banks to offset this balance sheet risk with a higher share of notionally safe public sector loans. In our firm-bank-level analysis below, we formally dispel this concern using a granular instrumental variable procedure.
} 
during this major recession. Our results here complement those of Becker and Ivashina (2018) by showing that-due to the segmentation of local banking markets-there is intra-national variation in the strength of this crowding out channel and that its economic cost is primarily borne by the least elastic customers, i.e. small and medium sized companies. Importantly, we show how crowding out could happen against the backdrop of a booming German economy of the last decade and of secularly low interest rates.

In its use of matched bank-firm data, our analysis builds on the seminal work by Khwaja and Mian (2008) and the literature spawned by this paper. Huber (2018) examines how an exogenous shock to Commerzbank, one of Germany's few big private banks, affected its dependent firms and counties in the aftermath of the financial crisis. While we make use of the same data source, our analysis benefits from access to historic volumes to obtain time-varying bank connections. Popov and Rocholl (2018) show that external financing shocks to savings banks lead to a decline in labor demand of firms which are connected to savings banks. Related, Bian et al. (2017) show that German firms with a government-owned bank as their main bank have lower innovation rates.

While these papers focus on credit supply shocks that adversely affect the length of the balance sheet of banks, our paper draws attention to how local banks' mandate to engage in municipal lending imposes constraints on the composition of savings banks' balance sheets and thus lead to reduced lending to firm customers ceteris paribus. At a methodological level, our analysis specifically addresses some potential biases that could arise in studies using bank-firm level data, e.g. because firms sort to specific banks or because there is some other form of reverse causality from firm characteristics to bank balance sheets. We do so by exploiting the unique information about the sectoral composition of bank portfolios that is implicit in our data set to construct a granular instrumental variable following the lead of Gabaix and Koijen (2020). ${ }^{5}$

One of our key contributions to show that (and how) crowding out can happen against the backdrop of a secular decline in interest rates. In our setting declining municipal borrowing rates exacerbate the statutory public lending constraints of local public banks and thus impose a shadow cost that they try to roll over to their customers. Our analysis therefore directly relates to recent studies that have investigated the impact of low and negative interest rates on bank behavior (Heider et al. (2019), Brunnermeier and Koby (2019), Balloch and Koby (2019), Basten and Mariathasan (2018)).

Heider et al. (2019) show that banks that mainly rely on deposit funding (i.e. are deposit-dependent) are particularly hit by the introduction of negative interest rates in the euro area. These banks cannot easily pass on negative rates to customers which implies comparatively higher cost of funding. As a consequence, depositdependent banks increase their interest rates and reduce lending.

\footnotetext{
${ }^{5}$ Pinardon-Touati (2020) shows how some of these challenges can be overcome using loan-level data instead. Her results confirm ours by documenting a bank-lending channel of crowding out in French data.
} 
Brunnermeier and Koby (2019) offer an elegant theoretical analysis of the impact of persistently low interest rates on bank lending. They show that the impact of interest rates on bank lending is not monotonic, i.e. there exists a minimum level of monetary policy rates, referred to as the reversal rate, below which bank credit supply starts to decrease. We propose an extension of Brunnermeier's and Koby's model by adding a statutory public lending constraint to the banks problem. This model provides guidance for our empirical analysis.

Balloch and Koby (2019) examine the long-run impact of low interest rates on bank profitability and bank lending in Japanese data and find that the effect of low rates is particularly pernicious for deposit-dependent banks. In our empirical setting, both types of local banks - cooperative banks and savings banks-are depositdependent and, as shown by Heider et al. (2019), their business models have been affected by declining monetary policy rates. We add to these papers by arguing that the ability of savings banks to adjust to declining interest margins is particularly constrained by their mandate to engage in municipal lending. Coupled with the local segmentation of banking markets, this leads to a crowding out of private sector lending and thus of private investment. This aspect of low interest rates has not been discussed in the literature so far. Our results show that this effect is quantitatively important. Our mechanism is potentially relevant in other settings as well since public sector banks are a feature of the banking landscape in many countries.

Our analysis is also informed by a number of recent papers that have shown that lending decisions of Germany's savings banks are subject to political influence. Englmaier and Stowasser (2017) document an electoral cycle in the lending of Germany's savings banks. Markgraf and Rosas (2019) show that mayors who sit on the boards of German savings banks are more likely to get re-elected than their peers who are not board members. Koetter and Popov (2021) suggest that local governments try to curry favor with state-level governments of a different party by letting their savings banks increase their holding of state-level bonds. Different from these papers, our analysis benefits from having access to matched bank-firm data. This allows us to identify the specific channel through which real outcomes are affected.

We also place our results against the backdrop of a recent literature that documents a secular rise in corporate net savings since the 1980s. Chen et al. (2017) and Dao and Maggi (2018) argue that this increase is a global phenomenon that affects all industrialized economies. However, these studies generally focus on large, listed firms. By contrast, Germany's local banks predominantly lend to SMEs and our results are therefore driven by small, non-listed firms, Germany's famous "Mittelstand". Ours is the first paper to document the low investment rates of German "Mittelstand" firms and to draw attention to their financing situation as one of its causes.

Our results also contribute to the literature on local fiscal multipliers (Nakamura and Steinsson (2014); Adelino et al. (2017)) and, more generally, the literature on the potentially pernicious effects of fiscal austerity (see e.g. Fetzer (2019)). It is particularly interesting to study the link between local public finance and firm 
investment in the German context of the last decade because Germany was one of the global leaders in the drive to fiscal austerity. Our results show how fiscal austerity can backfire in unexpected ways. When credit markets are locally segmented, preferential lending of local public banks to local governments creates an adverse effect on the real economy. In other words: if municipalities were to finance their debt through bonds or at the national or international level, the adverse effects on the local economy would plausibly be much smaller. ${ }^{6}$

Last but not least, by focusing on the role of preferential lending by government-controlled banks, our paper connects to a classic study by Song et al. (2011) which also inspires the title of our paper. Song et al. (2011) argue that China's persistent current account surpluses are ultimately the result of a domestic misallocation of capital: since only politically connected (state-owned) firms can borrow from the banking sector, domestic private firms are required to finance investment from internal funds. This keeps private sector investment lower than it would otherwise be. While the details of our mechanism differ, our analysis reveals that the basic insight that current account surpluses can be the reflection of domestic financial frictions, can usefully be applied to a developed economy. In our setting it is the requirement for savings banks to lend to politically connected borrowers (municipalities) that forces local banks to impose tighter funding conditions on unconnected borrower firms.

\section{Data and empirical framework}

\subsection{Data sources}

We build a data set of firm outcomes and firm-bank relationships matched with lending statistics for the banks. To this end, we rely on two data sources, Dafne and FitchConnect.

Dafne is a data base provided by Bureau van Dijk which contains the balance sheets and income statements for up to 1.4 million German firms based on annual reports of the companies. Dafne also contains bank relationships for the majority of firms. Since bank relationships are overwritten in each year, we make use of historical volumes of the data base to obtain a panel of firm-level data. This panel also provides us with time-varying bank-firm connections.

To proxy investment behaviour of the firm, we compute the investment rate as the difference in fixed assets from $t$ to $t+1$ divided by fixed assets in $t$. We measure the effective interest rate paid by the firm using the ratio of interest payments over last period's bank liabilities. We compute bank liabilities growth as the $t$ to $t+1$ change in bank liabilities divided by bank liabilities in $t$.

\footnotetext{
${ }^{6}$ Recall that our identification exploits matched bank-firm data and a de-facto control group of firms borrowing from other (cooperative) local banks. This allows us to effectively rule out that low firm investment is driven by a direct negative multiplier effect of fiscal austerity on local or sector-specific demand.
} 
Our main measure of firm size is the natural logarithm of total assets. We compute equity and cash flow shares as the ratio of the respective variable to total assets.

We merge our firm-level data set with bank-level information from FitchConnect, a database provided by Fitch which contains historical bank balance sheets. We extract information on the net interest margin, net loans, and on public sector loans. Public sector loans in the bank balance sheet data comprise all lending to public borrowers, including the lending to public owner-operated enterprises and municipal enterprises without legal capacity ("Eigenbetriebe") which are legally part of their respective municipality but whose financial budgets are formally separate. We compute municipal lending shares as the ratio of public sector loans to total bank assets. Data on public sector loans in Fitch Connect are available from 2009. For this reason and because our interest is in the recent, post-crisis period of Germany's high current-account surpluses, our empirical analysis in this paper generally focuses on the period 2010-2016.

\subsection{Public sector lending and private-sector borrowing rates}

The decline of the municipal spread that we documented in Figure 4 is a particular problem for Germany's local public banks. By their statutory mandate they have to provide financing to the public sector. At the same time, they are generally highly dependent on local deposits and their mandate as retail bank for the masses makes it much harder for them than for commercial banks to charge negative deposit rates, increase fees or to make cuts to their dense (and expensive) branch networks. We argue that, over our sample period, these constraints lead Germany's local public banks to charge their least elastic SME customers higher interest rates than they would otherwise have done.

In the appendix, we provide a simple model inspired by Brunnermeier and Koby (2019) to formalize this idea. In the model, banks have market power in local SME lending markets. As in Brunnermeier and Koby (2019), all banks face an equity constraint. They also face a supply of deposits that is not perfectly elastic. In addition, because of their public mandate, local public banks also have a statutory requirement to hold a minimum fraction of their balance sheet in the form of local public debt.

The model predicts that the bank will charge its other customers (i.e. SMEs) higher interest rates if the statutory public lending requirement is binding. As long as the banks' supply of deposits is not perfectly elastic, a binding constraint on public sector lending leads to inefficiently low provision of credit to other customers. In order to at least partially make up for this, a profit-maximizing bank will therefore use its market power to charge higher SME lending rates than it would do otherwise. We refer to this differential between the constrained and the unconstrained lending rate as the break-even spread, $\theta$. The break-even spread captures the 
banks' success at making up for the shadow cost of a binding statutory public lending requirement and is our measure of the extent to which this requirement crowds out SME lending. Formally, the model allows us to write the SME (firm) lending rate $i_{t}^{F, b}$ of bank $b$ in year $t$ as

$$
i_{t}^{F, b}=\theta_{t}^{b}+i_{t}^{U, b}
$$

where $\theta_{t}^{b}>0$ is bank $b$ 's break-even spread at time $t$ and $i_{t}^{U, b}$ is the lending rate that the bank would set if it was not constrained by the statutory public lending requirement. The break-even spread $\theta_{t}^{b}$ reflects the shadow price on the statutory public lending constraint which stipulates that the share of municipal lending, $\lambda_{t}^{b}$ must not fall below an exogenously given bank-specific threshold $\bar{\lambda}_{t}^{b}$. In appendix A we show that the break-even spread can be written as

$$
\theta=\frac{\frac{1}{\varepsilon_{D}}-\left(i^{P}-i^{D}\right)}{1-\bar{\lambda}}
$$

where $\varepsilon_{D}$ is the elasticity of deposit supply, $i^{P}$ is the lending rate for public sector loans (common across all banks) and $i^{D}$ is the bank's deposit rate. For notational convenience, we have suppressed the bank and time index. Three features of equation 2 are worth highlighting.

First, equation (2) implies that, for constrained banks (for which $\lambda=\bar{\lambda}$ ), the break-even spread will be increasing in $\lambda$. Note also that an exogenous increase in $\bar{\lambda}$ will make it more likely that the statutory public lending requirement becomes binding for previously unconstrained banks. In the second part of the paper, we argue that an exogenous increase in the fiscal burden imposed on municipalities by state-level debt brakes increased the lower bounds $\bar{\lambda}$ for the local savings banks. This will allow us to use the debt brake as an instrument for the $\lambda$ of savings banks.

Secondly, as can be seen from the first term in the numerator, banks with a less elastic supply of funds (deposits), will charge a higher break-even spread ceteris paribus. The less elastic the supply of deposits to the bank, the costlier it is to raise additional funds to satisfy the statutory lending requirement. Hence, a less elastic balance sheet forces the bank to curtail lending to firms more. Since the bank has market power in the SME lending market, this reduction in lending will happen through an increase in the spread charged to SME customers. We note that the assumption that banks' balance sheet is not fully elastic is likely to be satisfied for Germany's local banks (both cooperative and public) with their heavy reliance on deposits. ${ }^{7}$

Third, equation (2) predicts that an exogenous decline in the municipal spread $i^{P}-i^{D}$ leads to a higher

\footnotetext{
${ }^{7}$ In the next subsection, we discuss how to estimate $\theta$ from data on $\lambda$ and the municipal spread. In this setting the assumption that $1 / \varepsilon_{D}=0$ becomes easily testable for constrained banks and is rejected by the data. See also our discussion in appendix A and the additional empirical results discussed there.
} 
break-even spread. The intuition here is that the decline in $i^{P}-i^{D}$ makes it less attractive to invest in municipal loans and lowers the optimal (unconstrained) level of $\lambda$. This increases the shadow cost on the statutory public lending requirement. It also makes it more likely that the statutory public lending binds for previously unconstrained banks. This link between the municipal spread and the break-even spread is an important feature of our model since it can explain why our mechanism should be particularly pertinent to the low-interest rate environment of the last decade, during which spreads between municipal lending rates and banks' refinancing rates have been lower than ever before.

\subsection{Identifying break-even spreads in the data}

Note that neither $\theta_{t}^{b}$ nor in fact $i_{t}^{F, b}$ is directly observable. To explore the link between public loans and SME lending rates in the data, we therefore start from the following representation of the bank's net interest margin:

$$
\text { NetInterestMargin }{ }_{t}^{b}=\lambda_{t}^{b}\left(i_{t}^{P}-i_{t}^{D}\right)+\left(1-\lambda_{t}^{b}\right)\left(i_{t}^{F, b}-i_{t}^{D}\right)+(1-\delta) i_{t}^{D}
$$

where $\lambda_{t}^{b}$ is again the public (municipal) debt share of a banks' total lending and $\delta$ is the share of deposits in the bank's balance sheets. Furthermore, $i_{t}^{D}$ and $i_{t}^{P}$ denote the deposit rate, and the rate on public sector lending respectively and $i_{t}^{F, b}$ denotes the firm lending rate from above. ${ }^{8}$

In our bank data set, we directly observe the bank's net interest margin as well as the share of public sector loans, $\lambda_{t}^{b}$ and the deposit share $\delta$. To obtain an estimate of $i_{t}^{F, b}$, we have to make a few additional assumptions. First, we assume that $i_{t}^{P}$ is the same for all banks and that it is given by the benchmark rate of return on municipal bonds. ${ }^{9}$ Secondly, for the deposit rate $i_{t}^{D}$ we assume that the market for deposits is fully integrated across regions, so that deposit interest rates equalize across banks. We use the average deposit rate for all banks published by the Deutsche Bundesbank as our measure. ${ }^{10}$ Based on these assumptions, for each bank in our

\footnotetext{
${ }^{8}$ Strictly speaking, in this decomposition $i_{t}^{F, b}$ is the average borrowing rate of all private-sector customers of the bank. To what extent $i_{t}^{F, b}$ ultimately reflects firms borrowing conditions is therefore an empirical question. As we have argued before, SMEs are arguably the least elastic private borrowers so that we would expect them to bear the brunt of the real impact of this spread. We therefore identify this average private-sector borrowing rate with the firm lending rate $i_{t}^{F, b}$ of the bank. To the extent that other private borrowers (such as e.g. private households) are considerably more elastic in their credit demand, $i_{t}^{F, b}$ would actually tend to underestimate the effective interest rate and the break-even spread charged to firms.

${ }^{9}$ While direct evidence on the borrowing conditions municipalities face is scarce, we note again that loans to municipalities carry a risk weight of zero and that the federal states are ultimately liable for these loans. This suggests that spreads of individual loans to local governments over, say, German treasury bills are likely to be small and that the common component is likely to be dominant. Some indicative evidence can be gleaned from the risk premia on municipal bonds of major German cities that are around 25-30 basis points on average and appear rather uniform across cities (Friedrich et al. (2014)).

${ }^{10}$ Electronic banking has made it much easier for households to arbitrage small differences in deposit rates. Also, there is empirical evidence that banks' pricing power in deposit markets shrinks as interest rates decline towards zero, as has been the case for most of our sample period (Hainz et al. (2017)). At a more general level, we would expect that any heterogeneity in deposit rates in the data would be dwarfed by the heterogeneity in firm lending rates simply because the German market for deposits is much less segmented
} 
sample, we can then easily obtain a time-series of the firm-lending rate $i_{t}^{F, b}$ by rearranging equation (3).

Having thus obtained an estimate of $i_{t}^{F, b}$, we can use our model to identify the break-even spread $\theta_{t}^{b}$. Recall from equation (2) that our model implies a non-linear relationship between the municipal lending share $\lambda$ and the firm-lending rate. Defining $\Lambda_{t}^{b}=\frac{1}{1-\lambda_{t}^{b}}$ and plugging (2) into (1), we can estimate the relationship from the following panel regression

$$
i_{t}^{F, b}=\underbrace{\mathbf{a} \times \Lambda_{t}^{b}+\mathbf{b} \times \Lambda_{t}^{b} \times \operatorname{MUNICIPAL} \operatorname{SPREAD}_{t}}_{\theta_{t}^{b}}+\underbrace{\text { TIME }+ \text { REGION }+ \text { BANK CONTROLS }}_{i_{t}^{U, b}}
$$

which we run separately for the sample of Sparkassen and Volksbanken. This regression is our direct empirical counterpart to the decomposition (1) and to equation (2) above. Note that the first two terms on the right hand side capture the dependence of $i_{t}^{F, b}$ on the public lending share and on the declining spread of municipal borrowing rates over deposit rates and can therefore be associated with the break-even spread, $\theta_{t}^{b}$. The remaining terms on the right hand side capture time, regional and bank-level variation in firm lending rates.

The results are presented in Table 2 . Both coefficients $\mathbf{a}$ and $\mathbf{b}$ are significant only for the savings banks, not for cooperative banks. This is consistent with the prediction from our model, that a significant link between municipal lending and the firm-lending rate should only be present for banks that actually face a statutory lending constraint and for which it is binding. Also consistent with our model, the coefficient a is positive, while $\mathbf{b}$ is negative. In fact, we cannot reject that $\mathbf{b}$ is negative unity, the value predicted by our model. As public sector borrowing rates have declined, the shadow cost of a given level of public sector debt for constrained banks has increased, leading to higher borrowing rates for firm customers. ${ }^{11}$

\subsection{Constructing firm-level exposures: the local public bank spread}

We now construct firm-level exposures to the funding conditions set by local public banks. As we have shown in the previous subsection, differences in firm lending rates across banks and regions are related to the extent of the banks' municipal lending and to the general decline in the spread of public sector loans over the bank's refinancing rate. We therefore use estimates of regression (4) for the local public banks to back out an empirical along geographical lines than the market for SME lending.

${ }^{11}$ According to equation (2), for constrained banks the estimate of a corresponds to the inverse of the elasticity of banks' deposit supply, $1 / \epsilon_{D}$. Our estimates of $\mathbf{a}>1$ therefore imply that savings banks have a funding supply elasticity below one. We can therefore safely reject that savings banks operate in perfectly competitive funding markets. See appendix A for further discussion and empirical results. 
estimate of the break-even spread, $\widehat{\theta_{t}^{b}}$, as the fitted value

$$
\widehat{\theta}_{t}^{b}=\widehat{\mathbf{a}} \times \Lambda_{t}^{b}+\widehat{\mathbf{b}} \times \Lambda_{t}^{b} \times \text { MUNicipal SpREAD } t
$$

where $\widehat{\mathbf{a}}$ and $\widehat{\mathbf{b}}$ are the estimates of the respective coefficients in regression (4).

In a next step, we then combine the break-even spreads charged by local public banks with information on firms' bank relations to construct the average break-even spread that a firm is exposed to because it is connected to local public banks. For firm $f$ in year $t$ we define this exposure to spreads charged by local public banks, $\mathcal{S P \mathcal { K }}{ }_{t}^{f}$, as follows:

$$
\mathcal{S P} \mathcal{K}_{t}^{f}=\sum_{b \in \mathcal{B}_{t}(f)} \omega_{t}^{f, b} \times \widehat{\theta}_{t}^{b} \times \nVdash_{b=\text { Local PUBLIC BANK }}
$$

where $\mathcal{B}_{t}(f)$ is the set of all local banks with which firm $f$ maintains a lending relationship in year $t, \omega_{t}^{f, b}$ is the weight of the relation with bank $b$ and $\nVdash_{b=\text { Local public ваNк }}$ is an indicator variable for whether bank $b$ is a local public bank. We refer to $\mathcal{S P K}$ as local public bank spread.

We make two remarks concerning the construction of $\mathcal{S P K}$. First, our data set does not contain direct information about the amount of loans that a firm borrows from each bank. Also, even if this information was available, the actual extent to which each firm borrows from a bank could be endogenous to firm- or bank-level characteristics. Petersen and Rajan (1995) and Degryse and Ongena (2005) have shown that distance to the lending bank and the competitors is a key determinant of the lending conditions faced by SMEs. We therefore impute the weights $\omega_{t}^{f, b}$ based on the inverse of the geographical distance, dist ${ }^{f, b}$, between firm $f$ and the closest branch of bank $b$ :

$$
\omega_{t}^{f, b}=\frac{\frac{1}{1+\text { dist }^{f, b}}}{\sum_{j \in \mathcal{B}_{t}(f) \frac{1}{1+\operatorname{dist}^{f, j}}}}
$$

This weighting reflects the notion that distance is a key determinant of the intensity of a bank relation, in particular when lending is relationship-based, as is the case for Germany's SMEs.

Second, we note that an implicit assumption in constructing $\mathcal{S P K}$ is that cooperative and other banks do not charge a local public bank spread. This assumption is empirically justified by the results in Table 2 and reflects the different institutional constraints faced by local public and cooperative banks.In our empirical analysis below, we generate a placebo treatment by assigning non-zero values for $\widehat{\theta}_{t}^{b}$ to cooperative and other banks based on the procedure above. None of our main results holds under this placebo treatment, providing further evidence that our mechanism is driven by the institutional features of local public banks. 


\subsection{Firm-level regressions: estimation and identification}

We conjecture that higher levels of the local public bank spread lead firms to invest less. However, consistent with the literature on the firm-borrowing channel (Khwaja and Mian (2008)), the impact of $\mathcal{S P K}$ on firm-level outcomes should also depend on the firm's ability to tap alternative sources of finance. Our baseline specification therefore becomes

$$
\mathrm{INV}_{t}^{f}=\alpha \times \mathcal{S P} \mathcal{K}_{t}^{f}+\beta \times \boldsymbol{\eta}^{f} \times \mathcal{S} \mathcal{P} \mathcal{K}_{t}^{f}+\boldsymbol{\beta}^{\prime} \boldsymbol{X}_{\boldsymbol{t}}^{f}+\boldsymbol{\delta}_{t}^{f}+u_{t}^{f}
$$

where the dependent variable $\operatorname{INV}_{t}^{f}$ is the investment rate of firm $\mathrm{f}$ in year $\mathrm{t}$ and $\boldsymbol{\eta}^{f}$ is a generic measure of the firm's ability to substitute credit from local public banks with other funds, such as firm size, the availability of internal funds, firm age or the number of bank relationships. We therefore refer to $\boldsymbol{\eta}$ as the firm's substitution elasticity with respect to local public bank credit.

The vector $\boldsymbol{X}_{t}^{f}$ contains time-varying firm-specific controls and the vector $\boldsymbol{\delta}_{t}^{f}$ collects a range of fixed effects, including firm fixed effects, municipality-time and sector-time effects. Since $\boldsymbol{\eta}$ will generally be timeinvariant in our specifications, its stand-alone term will be absorbed by firm effects and is therefore not included above.

The marginal effect of $\mathcal{S P K}$ on investment (or other firm-level outcomes) is then given by $\alpha+\beta \times \boldsymbol{\eta}$, where we would expect that $\alpha<0$ and $\beta>0$ : the real impact of a higher local public bank spread is dampened for firms with a higher substitution elasticity. In our analysis below, we will generally measure $\boldsymbol{\eta}$ as deviation from the median value of the substitution elasticity for a reference group of firms (e.g. a sector). This normalization allows us to interpret $\alpha$ as an average treatment effect of $\mathcal{S P K}$ on firm-level investment in the respective reference group.

There are a number of reasons that underpin this causal interpretation. First, our use of matched bankfirm data effectively allows us to rule out a lot of factors that could confound our estimate of $\alpha$. Specifically, the break-even spreads used to compute $\mathcal{S P K}$ are constructed using bank's balance sheet information about public lending and aggregate information on the municipal spread only, while controlling for local and time variation in market interest rates and bank characteristics. Hence, $\mathcal{S P K}$ is likely uncorrelated with omitted time-varying firm-specific factors such as variation in the firm's demand for loans or a firm's riskiness. Second, $\mathcal{S} \mathcal{P K}$ exploits variation across firms in the same location in terms of their banking relations. This makes $\mathcal{S P K}$ uncorrelated with common, region-specific influences that affect all firms in the same location.

Our approach also takes account of potential threats to identification that could arise if specific firms match 
with specific banks. For example, it is well known that savings banks specialize in relationship lending to small and medium sized firms. If these firms happen to have lower investment rates, e.g. because they are less productive or subject to higher levels of idiosyncratic risk, this could bias the estimate of $\alpha$ towards the negative. We can effectively alleviate this concern because the composition of the customer base and the business model of local cooperative banks are very similar to that of savings banks and many small firms are customers of both types of banks. Since only the savings banks customers get exposed to the break-even spreads, the estimate of $\alpha$ is therefore unaffected by sorting of small firms to specific local banks.

\section{Firm-Level Results}

\subsection{Descriptive statistics}

Table 1 provides summary statistics for the main variables in our data set. The average of the local bank spread across all firm-year observations in our sample is 71 basis points. The variation across firms is also considerable. The standard deviation of $\mathcal{S P K}$ is 86 basis points. The average investment rate (as a fraction of assets) for the firm in our sample is around 15 percent, while the average interest rate firms pay on their liabilities is around 3 percent. Interest rates vary widely across firms, the standard deviation of interest rates paid by firms is of the same magnitude as the mean. Average bank liabilities growth across our sample of firms is around 1 percent per year, again with wide variation. The average firm has around $420000=1000 * \exp (6.04)$ EUR in assets and has a cash flow of 9 percent of total assets.

\subsection{Firm-level: baseline results}

As our baseline measure of the substitution elasticity $\boldsymbol{\eta}^{f}$ in the firm-level regression (8) we choose firm size as measured by the log of firms' total assets. We take the value in the first year of our sample (2010) and subtract the sector-median firm size in that year. This normalization ensures that the stand-alone coefficient $\alpha$ measures the marginal impact of $\mathcal{S P K}$ on the median firm in the firm's respective sector which facilitates the interpretation of our quantitative results. We estimate (8) using OLS and clustering standard errors at the municipal (county) level. Table 3 presents the results .

Column (1) shows a plain specification with time and firm fixed effects. Our estimate of the coefficient on $\mathcal{S P K}, \alpha$, is negative and significant. Conversely, the coefficient on the interaction term $\mathcal{S P K} \times \boldsymbol{\eta}$ is significantly positive, in line with our conjecture that bigger firms can more easily substitute loans from local public banks 
with other sources of finance and are therefore less exposed to $\mathcal{S P K}$.

In column (2), we add firm size and the equity share as firm-specific controls. We refer to these variables as the baseline controls as we will use them in most specifications throughout the rest of the paper. ${ }^{12}$ Adding firm-level controls hardly affects the estimate of $\alpha$.

Low firm-level investment could be the results of some regions or sectors being in relative decline or being exposed to specific adverse shocks. If, for some reason, local public banks are particularly active in these declining regions or if they lend primarily to certain sectors, this could lead to a correlation between these firm's investment rates and $\mathcal{S P K}$ that could bias our estimates of $\alpha$ downward. To rule out that our results are confounded by such regional or sector-specific factors, we include municipality-time effects in column (3) and also add sector-specific time effects in column (4). This decreases our estimate of $\alpha$ to around -0.8 but the coefficient stays highly significant. In column (5) we further tighten our specification, by including countysector-time dummies. This effectively allows sectoral factors to load differently on different regions and also controls for heterogeneous effects of regional factors across sectors. The estimate of $\alpha$ remains stable and significantly negative. We consider the specification in column (5) with our baseline set of firm-level controls and with firm-level and county-sector-time fixed effects as our benchmark for firm-level regressions in the rest of the paper.

In Table 4, we provide estimates of this benchmark specification for three alternative measures of the substitution elasticity $\boldsymbol{\eta}^{f}$ : (log) firm employment, firm age and the number of bank relationships of the firm. In column (1), for convenience, we also reproduce the baseline specification from column (4) of the previous table. Table 4 reveals the same pattern we have documented before. The coefficient $\alpha$ is negative and significant throughout and a higher ability to substitute funds lowers the impact of the local public bank spread on firmlevel investment. Our estimates of $\alpha$ vary somewhat across different specifications in Table 4 since by varying the concept of $\boldsymbol{\eta}$ we effectively normalize the stand-alone coefficient $\alpha$ to measure the marginal impact of $\mathcal{S P K}$ at very different points of the firm distribution.

It is instructive to gauge the economic significance of our estimates of $\alpha$ and to evaluate the impact of $\mathcal{S P K}$ on firm-level investment implied by the different specifications in Table 4.

Consider first our benchmark specification in column (1) (or, equivalently, column (5) of Table 3). The value of $\alpha$ of -0.88 means that a one-standard deviation increase in the local bank spread of around 85 basis points will lower the investment rate for the median firm by around 0.75 percentage points. With an average investment

\footnotetext{
${ }^{12}$ With these controls, derived from firm-balance sheets, our data set comprises roughly 1.8 mio observations. In the appendix we report results with an extended set of controls including e.g. revenue growth and cash flow that are derived from income statements. None of our main results is sensitive to this choice. However, the majority of firms in our data set only consistently report balance sheet items and not the income statements. Hence, including variables derived from income statements in the regression, considerably lowers the number of observations.
} 
rate of 15 percent of fixed assets across all firms, this amounts to a 5 percent $(0.0075 / 0.15)$ decrease in firm-level investment.

At the other end of the spectrum of estimates of $\alpha$, consider the specification where $\boldsymbol{\eta}$ is measured by firm employment in column (2). Here, the value of -3.48 implies that a one standard deviation increase in $\mathcal{S P K}$ lowers investment by almost 3 percentage points or 2 percent of the usual level of investment of the average firm.

Hence, the results in Table 4 show that firms invest considerably less in response to increases in their local bank spread. Since the local public bank spread ultimately reflects the shadow costs of municipal debt holdings across savings banks, our results suggest that local public debt crowds out private investment in Germany's locally segmented credit markets to a considerable extent.

To appreciate the magnitude of the sensitivity of investment to local public bank spreads, we relate our estimates to earlier studies in the literature.

Consistent with Gilchrist and Zakrajsek (2007) and Guiso et al. (2002) we find that investment is highly sensitive to truly exogenous measures of firm interest rates. ${ }^{13}$ Our most conservative baseline estimate for $\alpha$ implies that a 100 basis point increase in the interest rate lowers investment by 90 basis point. This is only slightly higher than the 75 basis points reduction found by Gilchrist and Zakrajsek (2007).

While of the same order of magnitude, the sensitivities implied by the other specifications in Table 4 are 2-3 times higher. To understand this discrepancy, note that Gilchrist and Zakrajsek (2007)'s estimates are based on a sample of big, listed and bond-issuing firms from the period before the financial crisis. We would expect that the smaller and more opaque firms that dominate in our sample are considerably more sensitive to changes in financing conditions. Furthermore, as recently highlighted by Lin et al. (2018), the secular drop in interest rates since the financial crisis and the commitment of monetary policymakers to keep rates low for long will considerably increase the sensitivity of investment to small changes in interest rates. Against this backdrop, it may not appear surprising that the estimates by Gilchrist and Zakrajsek (2007) should provide a lower bound on our estimates here. ${ }^{14}$

\footnotetext{
${ }^{13}$ The early literature in this area based on macro or sectoral time series evidence generally found it difficult to establish a significant link between interest rates and investment. As discussed by Guiso et al. (2002), studies based on firm-level evidence that use truly exogenous shifters in firm's cost of capital (such as e.g. tax reforms or indicators of firm-level interest rates constructed using banklevel information, as we do here) tend to find much larger effects.

${ }^{14}$ The finding that small spreads have a relatively bigger impact on SME investment in a low-for-long environment also has implications for the transmission of monetary policy. If average borrowing rates are low, then relatively small frictions in the financial system may have a disproportionate effect on firm-level investment. This can frustrate attempts by the monetary authority to stimulate the economy with low or negative interest rates.
} 


\subsection{Transmission mechanism}

Reduced borrowing by firms Our theory would predict that higher local public bank spreads lead to a deterioration of credit terms and to reduced lending to customer firms. Table 5 provides evidence to this effect.

Here we re-run our baseline regression with the growth rate of firms' bank liabilities (column (1)) and the average interest rate firms pay on their loans (column (2)) as the dependent variables. Higher exposure to $\mathcal{S P K}$ lowers firms' bank borrowing. The estimated coefficient on $\mathcal{S P K}$ in column (1) implies that a 100 basis points increase in the local bank spread would lower firms' bank borrowing by about 7 percent. The results in column (2) suggest that the average interest rate that firms pay on their outstanding bank liabilities increases by around 25 bps after a 100 bps increase in $\mathcal{S P K}$.

Crowding out of private investment should only be possible in segmented credit markets where the savings banks have sufficiently high market power. If firms can easily switch away from the savings banks, then variation in $\mathcal{S P K}$ should have no bearing on real outcomes. Table 6 illustrates that the local segmentation of Germany's credit market is indeed an important ingredient of our mechanism. The table reports results for investment, bank liability growth and the average interest rates paid by firms on two sub-samples: one for firms head-quartered in counties where savings banks account for a high (above-median) share of all bankfirm relationships (high segmentation) and one for firms head-quartered in counties with a low share of savings banks in firm-bank relations (low segmentation). In the investment regression, our estimate of $\alpha$ in the high-segmentation counties (columns (1)) is significant and much higher than when estimated with the same controls on the whole sample (compare column (4) of Table 3). Conversely, the coefficient is much lower and insignificant when estimated on the low-segmentation sample (column (2)). The same pattern holds for the bank-liability growth and interest rate regressions. $\mathcal{S P K}$ has a much stronger bearing on firm-level outcomes in the high-segmentation counties (columns (3) and (5)) than in the low-segmentation counties (columns (4) and (6)).

Placebo treatments To further illustrate the particular role that the local public banks play for our results, we repeat our analysis using a placebo treatment. To this end, we construct a break-even spread for the local cooperative banks using the bank-level regression in column 3 of Table 2 while setting the break-even spreads for the savings banks to zero. We then re-construct $\mathcal{S P K}$ using this set of break-even spreads and re-estimate the previous firm-level regressions. The results are in Tables B.1 in the appendix. As is apparent, the local public bank spread $\mathcal{S P K}$ is insignificant for investment but also for the two variables that should play a central role for submission: firms' bank liability growth and the average interest rate they pay. 


\subsection{Granular IV estimation}

An important assumption underlying our identification strategy is that local public banks' break-even spread are exogenous with respect to firms' investment decisions after controlling for our rich set of time-varying sector and regional effects.

In this subsection we probe this assumption empirically. Specifically, our identification strategy would be threatened if certain firms select to savings banks based on some unobserved or uncontrolled firm-specific characteristics and if the local public bank spread is affected by these characteristics. For example, this could be the case if local savings banks are charging a higher interest rate when lending to particularly risky firms in certain sectors that other banks do not want to lend to. The number of such firms might be particularly high in distressed areas with high public debt levels (and therefore high municipal lending shares). In this setting higher local public bank spreads would arise because firms connected to savings banks are risky and not because the statutory public lending requirement imposes a shadow cost on the bank. In the same mould, it could be that municipal lending and high public expenditures of local government affect demand of savings-bank dependent firms more strongly than their peers connected to local cooperative banks. This could lead them to demand more loans, leading to higher local public bank spreads. In both cases, we would then have a reverse causality between firms' investment and public banks' break-even spreads.

Making this point more formally, assume that our measurement of banks' break-even spreads is correlated with an unobserved vector of factors $F_{t}$, so that

$$
\widehat{\theta}_{t}^{b}=\phi_{t}^{b} / F_{t}+\zeta_{t}^{b}
$$

where $\phi_{t}^{b}$ is a vector of bank-specific loadings on $F_{t}$ and $\zeta_{t}^{b}$ is the 'true' break-even spread that is uncorrelated with $F_{t}$.

If $F_{t}$ is for some reason correlated with firm investment, then the estimated residual of the investment equation (8) will be $\widehat{u}_{t}^{f}=u_{t}^{f}+\gamma_{t}^{f \prime} F_{t}$ for some vector of firm-specific loadings $\gamma_{t}^{f}$ and our OLS estimate of $\alpha$ would be biased.

To check to what extent our OLS results are affected by such confounders, we propose to adapt the granular instrumental variable (GIV) approach pioneered by Gabaix and Koijen (2020). Specifically, assume for a moment that we had estimates of the factors $F_{t}$ and the loadings $\phi_{t}^{b}$. Then we can obtain an estimate $\widehat{\zeta}_{t}^{b}$ of the exogenous part of the break-even spread and construct the granular instrumental variable 


$$
\mathcal{G} \mathcal{I} \mathcal{V}_{t}^{f}=\sum_{b \in \mathcal{B}_{t}(f)} \omega_{t}^{f, b} \times \widehat{\zeta}_{t}^{b}
$$

where $\mathcal{B}_{t}(f)$ is again the set of banks with which firm $f$ maintains relations and $\omega_{t}^{f, b}$ is our set of distance weights from 6 above. $\mathcal{G I} \mathcal{V}_{t}^{f}$ would be a valid instrument for $\mathcal{S P K}$ because $\widehat{\zeta}_{t}^{b}$ is correlated with $\mathcal{S P K}$ via $\widehat{\theta}_{t}^{b}$ while being uncorrelated with the vector of confounders $F_{t}$ by construction.

Estimation of the confounding factors $F_{t}$ could be done jointly with the loadings $\phi_{t}^{b}$ using some factoranalytical technique. Alternatively, we could use some economic theory to parametrize the loadings in terms of economic observables. This is the approach we follow here. In particular, we make use of of the structure of our data set and interpret $\phi_{t}^{b}$ as the vector of sectoral portfolio weights of bank $b$. While our data set does not contain the actual amount bank $b$ lends to each firm, it allows us to compute the number of firms connected to each bank and also the share of each sector in the banks' firm relationships. In this way, we obtain a time-varying sequence of sectoral proxy portfolio weights for each bank which we take as our loadings $\phi_{t}^{b}$. Once the loadings $\phi_{t}^{b}$, are known, the factors $F_{t}$ in (9) can now easily be estimated by running a cross-sectional regression of the break-even spreads on the banks' portfolio shares for each year. ${ }^{15}$ To obtain an optimal, precision-weighted instrument in the sense of Gabaix and Koijen (2020), we estimate (9) using weighted least squares with the weights given by the inverse of the bank-specific mean of $\Lambda_{t}^{b}{ }^{16}$ We construct $\mathcal{G} \mathcal{I} \mathcal{V}_{t}^{f}$ using the residual of this regression as our measure of $\widehat{\zeta}_{t}^{b}$.

In Table 7 we report results using $\mathcal{G I V}$ and its interaction with $\boldsymbol{\eta}$ as instruments for $\mathcal{S P K}$ and its interaction with $\boldsymbol{\eta}$. Our earlier conclusions prevail: firms exposed to higher break-even spreads have significantly lower investment and bank liability growth, and the effect on interest rates is significantly positive. The first-stage regressions (for $\mathcal{S P K}$ and its interaction with $\boldsymbol{\eta}$ respectively) are both highly significant. Since we have more than one endogenous variable, we also have to check that the instruments span the space of the endogenous regressors, i.e. that they are linearly independent. To this end, we use the Sanderson and Windmeijer (2016) conditional F-statistics and bootstrap its p-values using 1000 replications. These signal that the instruments (GIV and its interaction with $\boldsymbol{\eta}$ ) are indeed linearly independent. Turning to the quantitative economic interpretation of the IV estimates, we note that the point estimates of $\alpha$ in all three regressions are very similar to

\footnotetext{
${ }^{15}$ To keep the number of factors manageable, we limit ourselves to the sectors which on average have the highest shares in the portfolios of local banks: manufacturing (NACE-1 code C), construction (F), commerce (G), and technical and professional services (M).

${ }^{16}$ Gabaix and Koijen (2020) show that it is efficient to weight the granular residuals $\widehat{\zeta}_{t}^{b}$ with the inverse of their volatility. However, our sample is relatively short, so that estimates of the volatility of $\widehat{\zeta}_{t}^{b}$ for individual banks are likely to be very noisy. We therefore take guidance from our economic theory: equation (2) states that banks' break even-spread should be more sensitive to exogenous fluctuations in the municipal spread if they have higher values of $\Lambda$, implying that these banks should have more volatile $\widehat{\theta}_{t}^{b}$.
} 
those obtained in our corresponding OLS specifications in column (5) of Table 3 and in Table 5. While the coefficients are a generally a bit bigger (in absolute value) than the OLS estimates, we have to bear in mind that the standard deviation of the first-stage fitted value of $\mathcal{S P K}$ at around 75 basis points is also slightly lower than that of $\mathcal{S P K}$ itself ( 85 basis points). Hence, our previous conclusions that a one-standard deviation increase in $\mathcal{S P K}$ lowers investment by around 5 percent, bank liabilities by around 7 percent and increases firms average interest payments by around 30 basis points remain virtually unaltered.

\section{The role of fiscal austerity}

Our results show that banks with higher public debt shares charge higher interest rates to their private borrowers and that this crowds out private investment in Germany's locally segmented banking markets. Against the background of Germany's recent fiscal consolidation over the last decade, this finding may appear surprising, at first. In this section, we provide evidence that fiscal austerity at the state and federal levels and the financing of public debt by local banks are two sides of the same coin.

Starting in 2009, the federal government and most federal states incorporated so-called debt brakes into the federal and state constitutions. These debt brakes stipulate that the federal government and the states may not incur new debt by 2016 and 2020, respectively. While some allowances are made for recessionary periods, the debt brakes limit the federal government to 0.35 percent of GDP and that of the states to zero in normal times.

We argue that the debt brake legislation generated exogenous variation in fiscal consolidation needs at the state-level that then impacted municipalities differentially depending on their specific fiscal situation at the time the debt brake came into being (2010). We exploit this variation to instrument the municipal lending share in our bank-level regressions. This allows us to answer the question what fraction of the crowding-out that we have documented in the data can be accounted for by fiscal consolidation.

As discussed before, the debt brake has encouraged state- and federal governments to shift expensive government tasks to the municipalities. ${ }^{17}$ Importantly, the constitutional debt brakes do not generally cover the debt of the municipalities. However, already prior to the introduction of the debt brake, the debt levels of many municipalities were so high that their ability to take on new expensive government tasks, let alone to generate new public investment, was severely impaired. We argue that fiscal consolidation needs at the state level directly

\footnotetext{
${ }^{17}$ Germany's parliamentary system puts considerable emphasis on finding a balance of power and compromise between the states and the federal government. However, while the federal and state-levels of government have direct parliamentary representation in the Bundestag (the lower chamber) and the Bundesrat (the upper chamber) respectively, municipalities as the lowest levels of government, have no such representation. This is what makes this burden-shifting politically possible in the first place.
} 
impacted municipalities and led to increased public debt shares on local bank balance sheets. ${ }^{18}$

Since municipalities have only very limited taxation powers, they had to fill the funding gaps through increased borrowing. Due to their statutory public lending requirement, we would expect this increased municipal credit demand to lead to increased municipal lending by savings banks, particularly in municipalities where there was high public debt to begin with. To make this point formally, we construct a measure of fiscal consolidation needs ('fiscal pressure') at the state level as follows:

$$
\mathrm{FP}_{t}^{s}=-\min \left(\text { Deficit }_{t}^{s}-\text { CoNSOLIDATION PATH }_{t}^{s}, 0\right)
$$

where $s$ indexes the federal state, Deficit $t_{t}^{s}$ is the state's public deficit relative to GDP and the term Consolidation Path denotes the projected structural deficit for state $s$ in year $t$ as stipulated by the debt brake. Introduced in 2010, the debt break requires that states close their structural deficits to zero by 2020 . The projected consolidation path therefore assumes that a state's 2010 deficit is reduced linearly until 2020. We then run the following bank-level regression for the period 2010-2016 on our sample of all local banks (cooperative and public):

$$
\begin{aligned}
\lambda_{t}^{b}= & \gamma \times \operatorname{Local} \operatorname{LublicDebT}_{2010}^{c}(b)+\delta \times \operatorname{LocalPublicDebT}_{2010}^{c}(b) \times \mathrm{FP}_{t}^{s(b)} \\
& +\phi \mathbb{1}_{b} \times \operatorname{LocalPublicDebT}_{2010}^{c}(b)+\rho \mathbb{1}_{b} \times \operatorname{LocalPublicDebT}_{2010}^{c}(b) \times \mathrm{FP}_{t}^{s(b)} \\
& +\psi \mathbb{1}_{b} \times \mathrm{FP}_{t}^{s(b)}+\kappa \mathbb{1}_{b}+\operatorname{Controls}_{t}^{b}+\nu_{t}^{b}
\end{aligned}
$$

where $\lambda_{t}^{b}$ is again the public debt share on local bank b's balance sheet, $\mathrm{FP}_{t}^{s(b)}$ is the pressure for fiscal consolidation in state $s(b)$ in which bank $b$ is located and LocalPublicDebtc ${ }_{2010}^{c}(b)$ is the ratio of outstanding local public debt to local GDP in municipality (county) $c(b)$, at the beginning of the sample period (2010) and $\mathbb{1}_{b}$ is an indicator dummy that is one if bank $b$ is a savings bank. ConTrols contains bank controls as well as stateand time fixed effects.

Regression (12) examines the link between banks' municipal lending share and local fiscal pressures for all local banks. It is effectively a diff-in-diff specification where the local cooperative banks are the control group. Estimation results are presented in Table 8. First, note that higher local public debt increases municipal lending for all local banks $(\gamma>0)$ but more so for savings banks $(\phi>0)$. Also, savings banks generally have a higher share of local public debt on their books $(\kappa>0)$. Importantly, only the savings banks react to pressures on local public finances by lending more to municipalities: We find $\rho>0$, while the corresponding coefficient for

\footnotetext{
${ }^{18}$ In line with our findings here, Fratzscher, Kriwolutzky and Michelsen discuss in Fuest et al. (2019) that higher levels of government increasingly passed legislation that shifted considerable financial burdens onto the municipalities. They cite social security payments, notably the cost of accommodation of households on social benefits or payments to asylum seekers as examples. In return, municipalities obtained a share of the tax revenue that federal states and the federal government raise, but these funds were generally insufficient to cover the additional expense imposed on municipalities by new legislation.
} 
the local cooperative banks is negative $(\delta<0)$. This suggests that cooperative banks become more cautious in their lending to local municipalities as fiscal pressures increase.

As a last exercise, we ask to what extent the impact of the debt brake on local public finances in Germany can explain the crowding out of private investment that we documented in our firm-level data. To this end, we take guidance from the results of regression (12) and generate a measure of the extent to which state-level consolidation needs weigh on local public finances. We refer to this measure as $\mathrm{LFP}_{t}^{b}$ or 'local fiscal pressure':

$$
\mathrm{LFP}_{t}^{b}=\frac{1}{1-\mathrm{LPD}_{2010}^{b} \times \mathrm{FP}_{t}^{s(b)}}
$$

We use $\operatorname{LFP}_{t}^{b}$ and its interaction with the municipal spread as instruments for $\Lambda_{t}^{b}=\frac{1}{1-\lambda}$ and $\Lambda_{t}^{b} \times \operatorname{MUNICIPALSPREAD}$ in the interest-rate regression (4) from above. These IV results are in Table 9. In line with our conjecture, local fiscal pressure is significantly correlated with municipal lending shares only for the savings banks, leading to strong first stages in the IV-regression, with both F-statistics exceeding 10. Also, the instruments have sufficient linearly independent variation as indicated by the high values of the conditional F-statistics proposed by Sanderson and Windmeijer (2016). By contrast, local fiscal pressure has almost no traction as an instrument for the municipal lending of the cooperative banks.

Turning to the second-stage estimates, we find them to be in line with those previously reported in Table 2 for the OLS regression. For the savings banks, the coefficient on $\Lambda_{t}^{b}$ is positive and bigger than one (though not quite significant in the second stage) while the coefficient on the interaction of $\Lambda_{t}^{b}$ with the municipal spread is significantly negative, around -1 , as suggested by the theory. Conversely, the estimates for the cooperative banks are small and insignificant again.

In a next step, we use our estimates of the bank-level IV regression in Table 9 to generate the break-even spreads according to equation (5). We then recalculate $\mathcal{S P K}$ with the resulting austerity-induced spreads, that we abbreviate with $\widehat{\theta}_{t}^{A, b}$, thus obtaining a measure of the austerity induced component of the local public bank spread (to which we refer with $\mathcal{S P} \mathcal{K}_{t}^{A, f}$ ). For easier comparison with our earlier findings, we rescale this "fiscal austerity induced" $\mathcal{S P \mathcal { K }}{ }^{A}$ to the same standard deviation as our baseline $\mathcal{S P K}$. We then re-run our previous firm-level regressions using this austerity-induced local public banks spread. The results are in Table 10. The first column is for investment, the second and third columns show results for the key transmission variables, bank liability growth and the average interest rate firms pay.

Table 10 clearly confirms our previous findings. The local bank shock has a significantly negative effect on investment and firms' borrowing and increases the average interest rate paid. Regarding the magnitude of 
the coefficient on the investment equation, it is roughly 70 percent of the size of the estimate in our baseline specification in column 4 of Table 3. This suggests that fiscal austerity over our sample period quantitatively explains between two thirds and three quarters of the crowding out effect induced by local public bank spreads.

\section{Extensions and robustness}

\subsection{Implications for aggregate investment}

In this section, we gauge the importance of our crowding-out mechanism for Germany's aggregate investment. Our aim is to provide a conservative estimate of the aggregate investment loss. To this end, we re-estimate our main specification from column (5) in Table 3 subtract the initial (2010) sector-regional mean from $\mathcal{S P K}$. In this way we take ex ante sector- and region-specific differences across firms in their exposure to the local public bank spread as given, counting only firm-specific dynamics in $\mathcal{S P K}$ over our sample period as contributing to our mechanism. We then aggregate the partial fitted value $\alpha \times \mathcal{S P K}+\beta \times \boldsymbol{\eta} \times \mathcal{S P K}$ across all firms in our sample, weighting each firm with is total fixed assets to obtain a measure of crowding out in our sample. We call this aggregate the predicted loss and subtract this loss from the aggregate gross investment that we obtain from firms in our Dafne sample. In this way, we obtain the counterfactual investment path that would have obtained in our sample in the absence of crowding-out.

Based on these in-sample calculations, we then extrapolate the effect on Germany's official aggregate investment data, by multiplying official investment with the ratio of the counterfactual to aggregate gross investment from our sample, thus obtaining a counterfactual investment path for aggregate German investment. ${ }^{19}$ Figure 6 presents time series for this counterfactual investment path along with the official investment data from the federal statistical office. Without crowding-out, aggregate investment in Germany over 2010-2016 could have been around 7 percent higher, amounting to around 35 billion Euros or roughly 1 percent of GDP per year. The gap is between actual and counterfactual investment bottoms out in the year 2012 with around 1.5 percent of aggregate investment or 8.5 billion Euro and rises to around 32 billion or 6 percent of aggregate investment by the end of the sample period. Notably, the increase after 2012 is quite consistent with our mechanism since 2012 is the year in which the ECB started quantitative easing and in which the spread between municipal borrowing and banks' refinancing rates - a key driver of our mechanism - reached zero for the first time in our sample (compare Figure 4). Note that our simple calculations here cannot take account of any multiplier effects

\footnotetext{
${ }^{19}$ This effectively assumes that our data base is sufficiently representative of Germany's economy as a whole. Indeed, investment of firms in the Dafne database accounts for roughly 50 percent of Germany's gross private investment over our sample period. The investment of firms in our regression sample (i.e. for which we have the full set of included covariates, in particular $\mathcal{S} \mathcal{P}$ ) in turn accounts for roughly 70-80 percent of aggregate investment in Dafne.
} 
that low private investment by treated firms may have in general equilibrium. However, to the extent that there are likely to be positive spillovers from treated firms' investment to the output and investment of non-treated firms and to local public finances, it is legitimate to speculate that our estimates could well constitute a lower bound of the aggregate effects of our mechanism. ${ }^{20}$

\subsection{Additional robustness checks}

Extended set of controls We also report results with an extended set of firm-level controls. See Table B.2 and B.3. In these regressions we include cash flow and revenue growth along with our baseline controls, i.e. firm size and the equity share. This substantial reduces our sample size since income statements are not reported for most firms in our sample. Still, our results remain qualitatively the same.

East-West Germany sample split Local banks have a different history in the western and eastern parts of Germany. In the 19th century, local banks were founded mainly in the west and the south of the country. During the communist era in East Germany, only big, state-run banks existed that were eventually dissolved following the reunification of the country in 1990. While the big West German banks started to enter the market in the east by opening new branches, local banks in East Germany essentially had to be founded anew in the years after reunification. To make sure that our results are not driven by some East-West divide, we also run our baseline regressions by splitting the sample into East and West. The results in Table B.4 show that our mechanism is not driven by some unobserved West-East divide. However, it is interesting to observe that the results are, if anything, qualitatively stronger in East Germany. This is consistent with the fact that East German firms are generally smaller than West-German ones (e.g. none of the big companies listed in the large-cap stock market index DAX is headquartered in East-Germany).

\section{Conclusion}

Germany's high current account surpluses have attracted increasing scrutiny in policy circles over the last decade. By contrast, the academic literature has given relatively little attention to this topic. In this paper, we draw attention to low private investment as one important driver of Germany's current account surplus. Specifically, we have shown how two key characteristics of Germany's banking system-local segmentation

\footnotetext{
${ }^{20}$ We thank Gianluca Violante and Thomas Drechsel for independently suggesting this point.
} 
and the role of local public banks in local government finance-have contributed to the crowding out of private investment. Our paper is the first to provide evidence of such local crowding out for a developed economy. It is also the first paper to provide detailed evidence that such crowding out happens through the balance sheet of local public banks.

Local banks dominate the market for SME lending in most of the country, contributing to significant local segmentation of credit markets for small corporate borrowers. Our analysis exploits Germany's unique institutional setting in which there are two types of local banks: local cooperative and local public banks. While both types of banks are similar in terms of their customer base of small and medium sized businesses and generally present in the same local market, local public banks also have a statutory mandate to lend to the local public sector while the cooperative banks do not.

We have argued that this statutory lending requirement is an important driver of the crowding out of private investment. Using a simple theoretical model, we have shown that the statutory lending requirement imposes a shadow cost on public banks' balance sheet. This shadow cost materializes as a spread on their lending rates to private customers, to which the least elastic private customers, SMEs, are also most strongly exposed. We document this mechanism empirically using matched bank-firm data covering more than 1 million German firms. Local public banks with higher levels of public lending charge their SME customers higher interest rates on average. This local public bank spread reduces the investment rate of these firms by an economically important margin. For the average firm, increasing the local public bank spread by 100 basis points will lower investment by around 5 percent. We estimate that aggregate investment in Germany would have been around 30-35 bio Euro per year (or roughly 1 percent of GDP) higher without this mechanism.

Our mechanism can also explain why crowding out of private investment can take place against the backdrop of secularly low interest rates. In fact, our theory implies that declining interest rates and decreasing intermediation spreads on municipal lending should have increased the shadow cost of the statutory requirement over time, leading them to increase the spreads they charge SME customers. Our empirical results strongly support this prediction and show that declining interest rates have led to more crowding out. Our analysis therefore also identifies a new channel through which quantitative easing and monetary policy with low-forlong interest rates can backfire by eventually reducing lending to the private sector.

Our findings also uncover a new channel through which fiscal austerity can have contractionary effects. Over the last decade, Germany's federal states and the federal government have tightened their spending under the influence of the debt brake introduced in 2010. It may therefore appear surprising that we find any evidence of crowding out in Germany at all. However, we have argued that fiscal austerity at the state- and federal levels and the financial distress of many municipalities are actually two sides of the same coin. In the process of 
fiscal consolidation, the federal and state governments have shifted many expensive government tasks to the municipalities, whose debt is explicitly exempted from the debt brake. Since municipalities' ability to raise taxes is very limited, they turned to local public banks for credit. Using the exogenous consolidation needs of statelevel budgets stipulated by the debt brake to to instrument for local public banks' municipal lending shares, we have shown that up to three quarters of the crowding out we observe over our sample period could be driven by fiscal austerity. 


\section{References}

Adelino, M., Cunha, I., and Ferreira, M. A. (2017). The Economic Effects of Public Financing: Evidence from Municipal Bond Ratings Recalibration. The Review of Financial Studies, 30(9):3223-3268. 10

Balloch, C. and Koby, Y. (2019). Low Rates and Bank Loan Supply: Theory and Evidence from Japan. Unpublished manuscript Brown University. 9, 10

Basten, C. and Mariathasan, M. (2018). How banks respond to negative interest rates: Evidence from the Swiss exemption threshold. CESifo Working Paper Series No. 6901. 9

Becker, B. and Ivashina, V. (2018). Financial Repression in the European Sovereign Debt Crisis. Review of Finance, 22:83-115. 8, 9

Bian, B., Haselmann, R., Vig, V., and di Mauro, B. W. (2017). Government ownership of banks and corporate innovation. Unpublished manuscript. 9

Brunnermeier, M. K. and Koby, Y. (2019). The Reversal Interest Rate. IMES Discussion Paper Series 19-E-06, Institute for Monetary and Economic Studies, Bank of Japan. 3, 9, 12

Chen, P., Karabarbounis, L., and Neiman, B. (2017). The Global Rise of Corporate Saving. Journal of Monetary Economics, 89:1-19. 10

Dao, M. C. and Maggi, C. (2018). The Rise in Corporate Saving and Cash Holding in Advanced Economies: Aggregate and Firm Level Trends. Working Paper 18/262, International Monetary Fund. 10

Degryse, H. and Ongena, S. (2005). Distance, lending relationships, and competition. The Journal of Finance, 60(1):231-266. 16

Englmaier, F. and Stowasser, T. (2017). Electoral Cycles in Savings Bank Lending. Journal of the European Economic Association, 15(2):296-354. 10

European Commission (2019). Kommission bewertet Reformfortschritte der Mitgliedstaaten: Ungleichgewichte auch in Deutschland. https://ec.europa.eu/germany/news/20190227-kommissionbewertet-reformfortschritte-mitgliedstaaten-ungleichgewichte-auch-deutschland_de. Accessed: 2020-04-08. 1

Fetzer, T. (2019). Did Austerity Cause Brexit? American Economic Review, 109(11):3849-86. 10

Friedrich, S., Walkshaeusl, C., and Lesser, C. (2014). The Pricing of German Municipal Bonds. Technical report, Kandler Gruppe. 14

Fuest, C., Gründler, K., Potrafke, N., Fratzscher, M., Kriwoluzky, A., Michelsen, C., Hüther, M., Bofinger, P., Feld, L. P., and Reuter, W. H. (2019). Schuldenbremse - Investitionshemmnis oder Vorbild für Europa? [Debt Brake - Investment Barrier or Role Model for Europe?]. Wirtschaftsdienst, 99(5):307-329. 25 
Gabaix, X. and Koijen, R. S. J. (2020). Granular Instrumental Variables. NBER Working Papers 28204, National Bureau of Economic Research, Inc. 4, 9, 22, 23

Gilchrist, S. and Zakrajsek, E. (2007). Investment and the Cost of Capital: New Evidence from the Corporate Bond Market. Working Paper 13174, National Bureau of Economic Research. 20

Gilquin, G. (2014). Der deutsche Bankensektor. Wirtschaftsdienst, 94(6):420-427. 2

Guiso, L., Kashyap, A. K., Panetta, F., and Terlizzese, D. (2002). How interest sensitive is investment? very (when the data are well measured). Unpublished manuscript (draft dated July 29). 20

Hainz, C., Marjenko, A., and Wildgruber, S. (2017). How the ECB’s Low-Interest Policy Impacts Firms: Results of the ifo Business Survey on them Effects of Negative Interest Rates for Bank Deposits. CESifo Forum, 18(03):21-24. 14

Heider, F., Saidi, F., and Schepens, G. (2019). Life below zero: Bank lending under negative policy rates. The Review of Financial Studies, 32(10):3728-3761. 9, 10

Huang, Y., Pagano, M., and Panizza, U. (2020). Local Crowding out in China. The Journal of Finance, 75(6):28552898. 1,8

Huber, K. (2018). Disentangling the Effects of a Banking Crisis: Evidence from German Firms and Counties. American Economic Review, 108(3):868-98. 9

Khwaja, A. I. and Mian, A. (2008). Tracing the Impact of Bank Liquidity Shocks: Evidence from an Emerging Market. American Economic Review, 98(4):1413-1442. 9, 17

Koetter, M. and Popov, A. (2021). Political Cycles in Bank Lending to the Government. The Review of Financial Studies, 34(6):3138-3180. 10

Lin, X., Wang, C., Wang, N., and Yang, J. (2018). Investment, Tobin's q, and interest rates. Journal of Financial Economics, 130(3):620 - 640. 20

Markgraf, J. and Rosas, G. (2019). On Board with Banks: Do Banking Connections Help Politicians Win Elections? The Journal of Politics. 10

Nakamura, E. and Steinsson, J. (2014). Fiscal Stimulus in a Monetary Union: Evidence from US Regions. American Economic Review, 104(3):753-792. 10

Petersen, M. A. and Rajan, R. (1995). The effect of credit market competition on lending relationships. The Quarterly Journal of Economics, 110(2):407-443. 16

Pinardon-Touati, N. (2020). Does Government Debt Crowd Out Corporate Investment? A Bank Lending Channel. Unpublished manuscript, HEC Paris. 9

Popov, A. and Rocholl, J. (2018). Do credit shocks affect labor demand? Evidence for employment and wages during the financial crisis. Journal of Financial Intermediation, 36:16-27. 9 
Sanderson, E. and Windmeijer, F. (2016). A weak instrument-test in linear IV models with multiple endogenous variables. Journal of Econometrics, 190(2):212 - 221. Endogeneity Problems in Econometrics. 23, 26, 46, 48

Sharpe, S. A. (1990). Asymmetric information, bank lending and implicit contracts: A stylized model of customer relationships. The Journal of Finance, 45(4):pp. 1069-1087. 2

Song, Z., Storesletten, K., and Zilibotti, F. (2011). Growing like China. American Economic Review, 101:202-241. 11

Trump, D. (2017). Tweet: "we have a massive trade deficit with germany, plus they pay far less than they should on nato \& military. very bad for u.s. this will change". https://twitter.com/realDonaldTrump/ status/869503804307275776?s=20. Accessed: 2020-03-30. 1 
Figure 1: Sectoral Decomposition of Germany's Net Lending

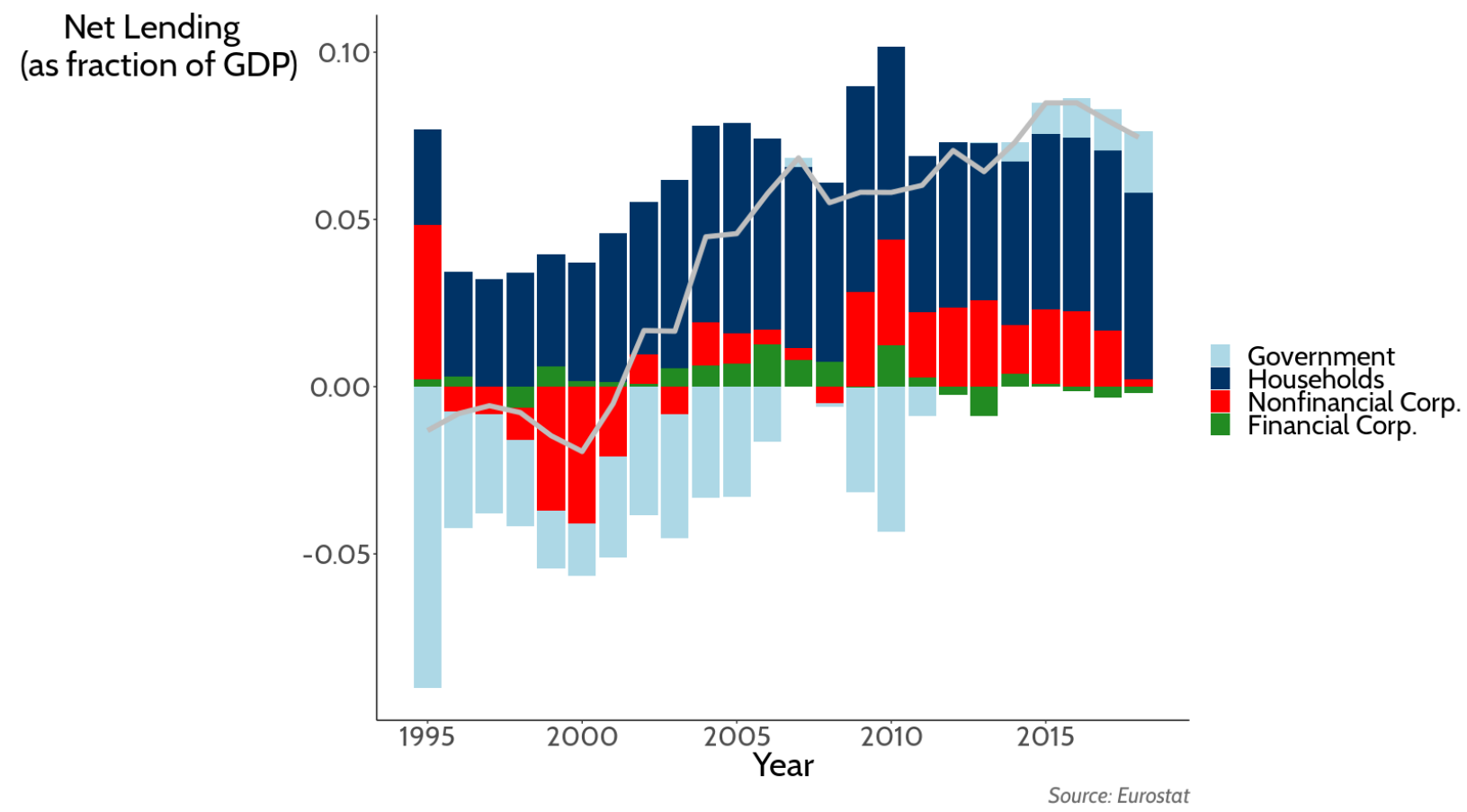

Note: The figure plots Germany's current account balance and its sectoral composition in terms of the ration of net lending to GDP. 
Figure 2: Map of local bank dependence

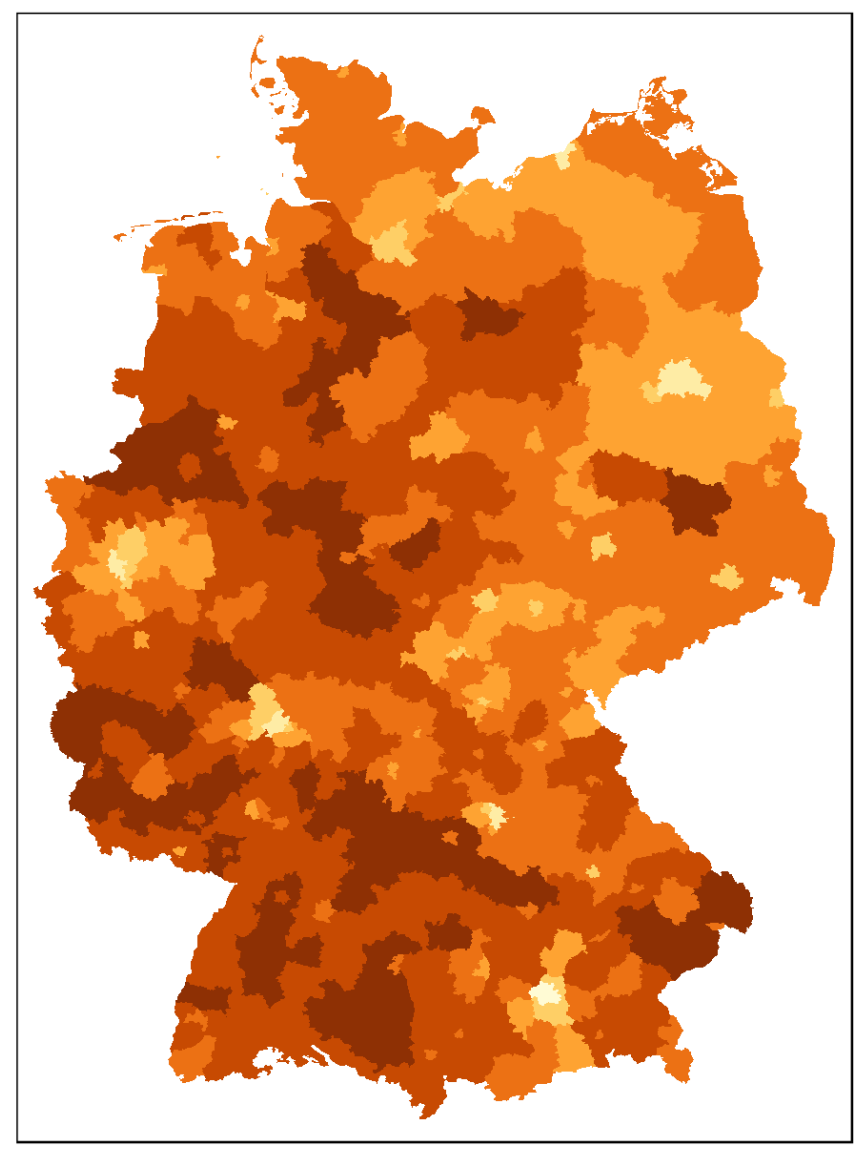

\section{Local Bank Dependence}

0.2 to 0.3

0.3 to 0.4

0.4 to 0.5

0.5 to 0.6

0.6 to 0.7

0.7 to 0.8

0.8 to 0.9

Note: This figure shows the dependence of firms on local banks in German counties in 2009. The dependence is computed as the share of savings and cooperative bank connections in the total number of bank connections in a county. 
Figure 3: Correlation between county-level public debt and local banks' public loans share

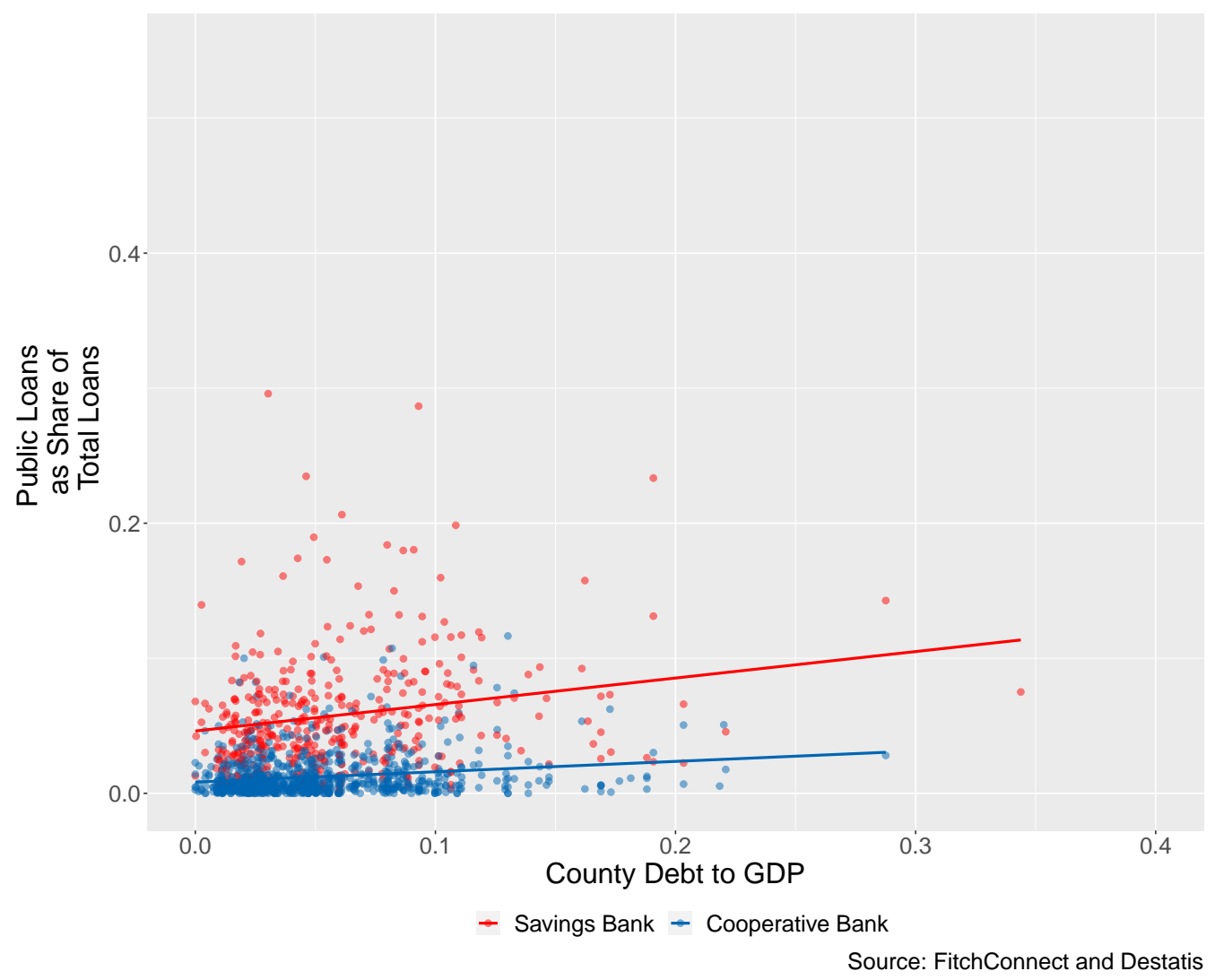

Note: Each dot represents a local bank in Germany. The y-axis indicates the share of public loans in total loans taken from the bank's balance sheet in 2010. The x-axis denotes the debt to GDP ratio of the county, in which the bank is based, also in 2010 . 
Figure 4: Average bank deposit rate and municipal bond rate

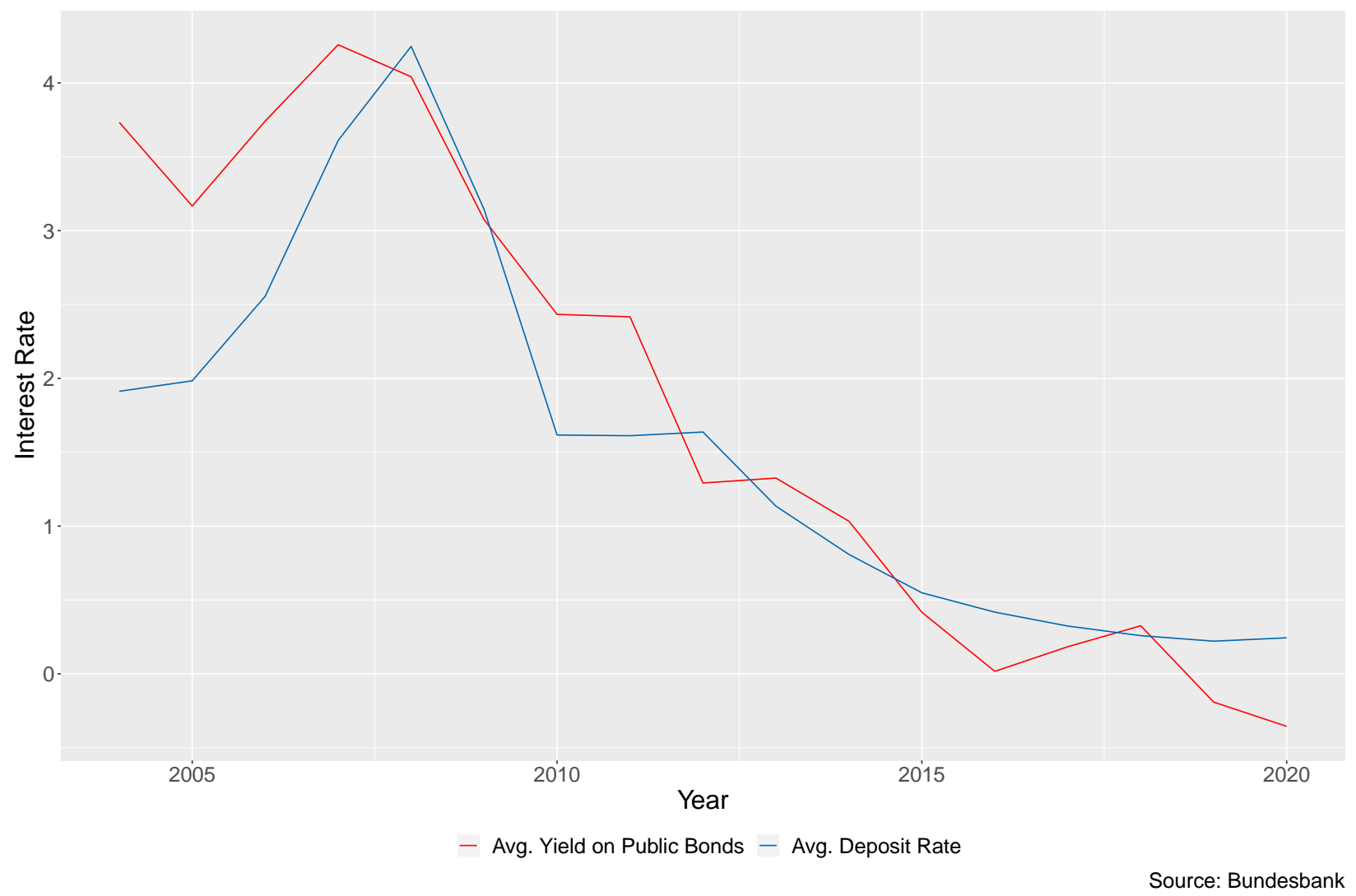

Note: This figure compares the average yield on public bonds ("Umlaufrendite") with the average short-term deposit rate for private households. 
Figure 5: Correlation between local banks municipal lending share and firm-lending rates
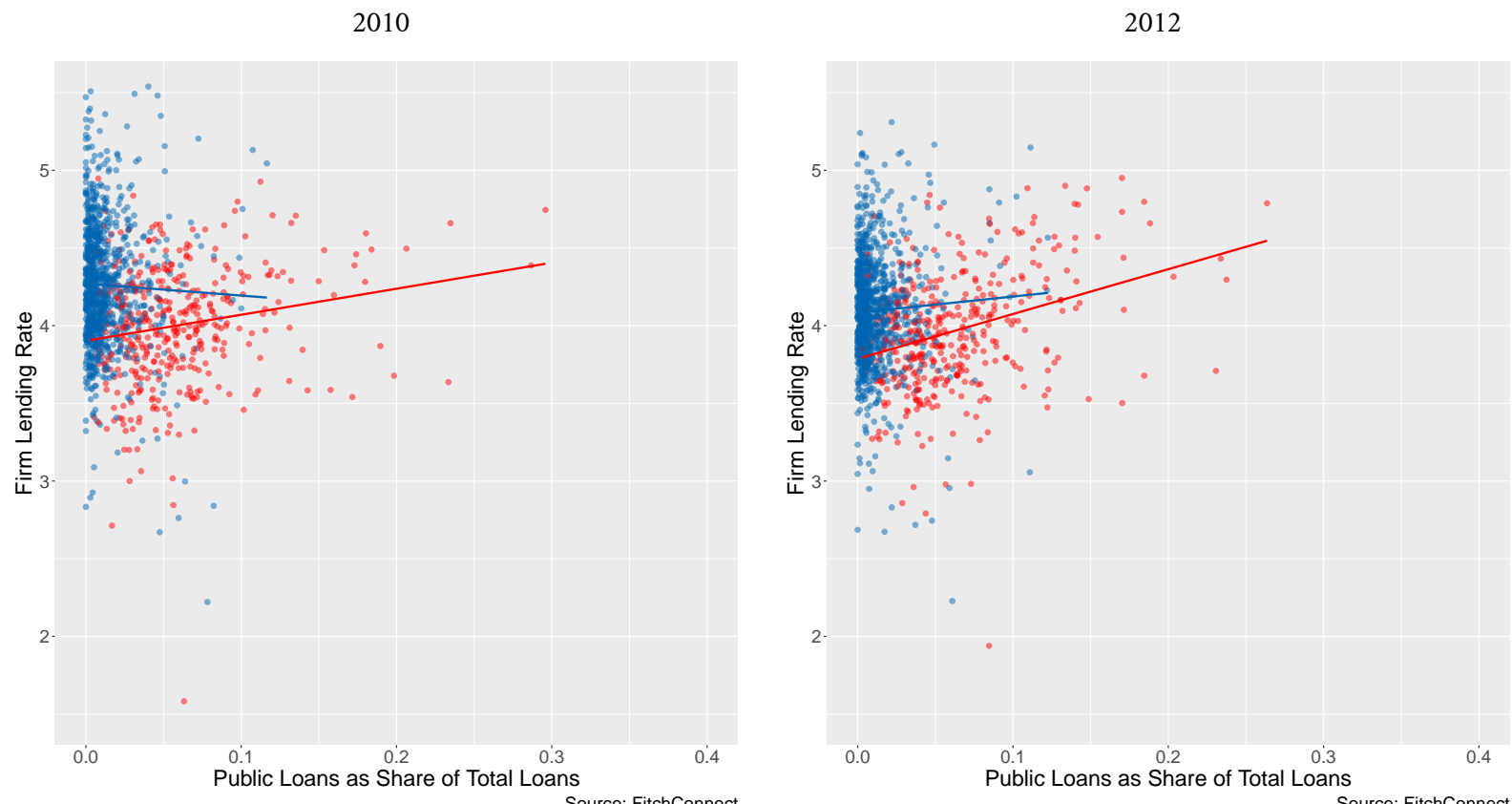

Source: FitchConnect

Source: FitchConnect

2014
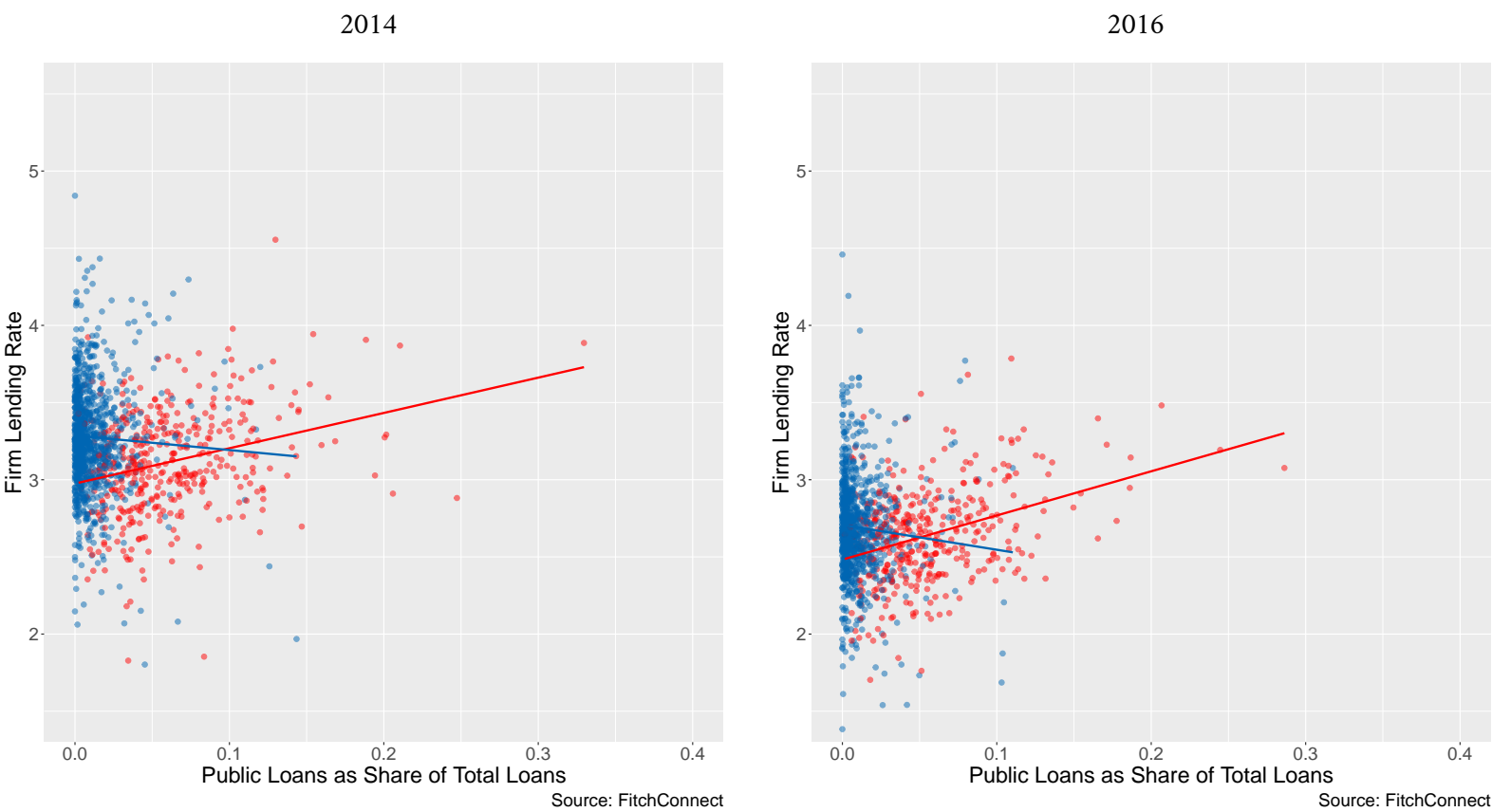

Source: FitchConnect

Note: Each dot represents a local bank in Germany, red for savings banks, blue for cooperative banks. The $\mathrm{y}$-axis indicates the firm lending rate which is imputed based on the identity in equation (3). The $\mathrm{x}$-axis denotes the public loans share from the bank balance sheet in the respective year. Red (blue) lines indicate the regression line for the savings and cooperative bank sub-samples respectively. 
Figure 6: Implications of crowding out for aggregate investment

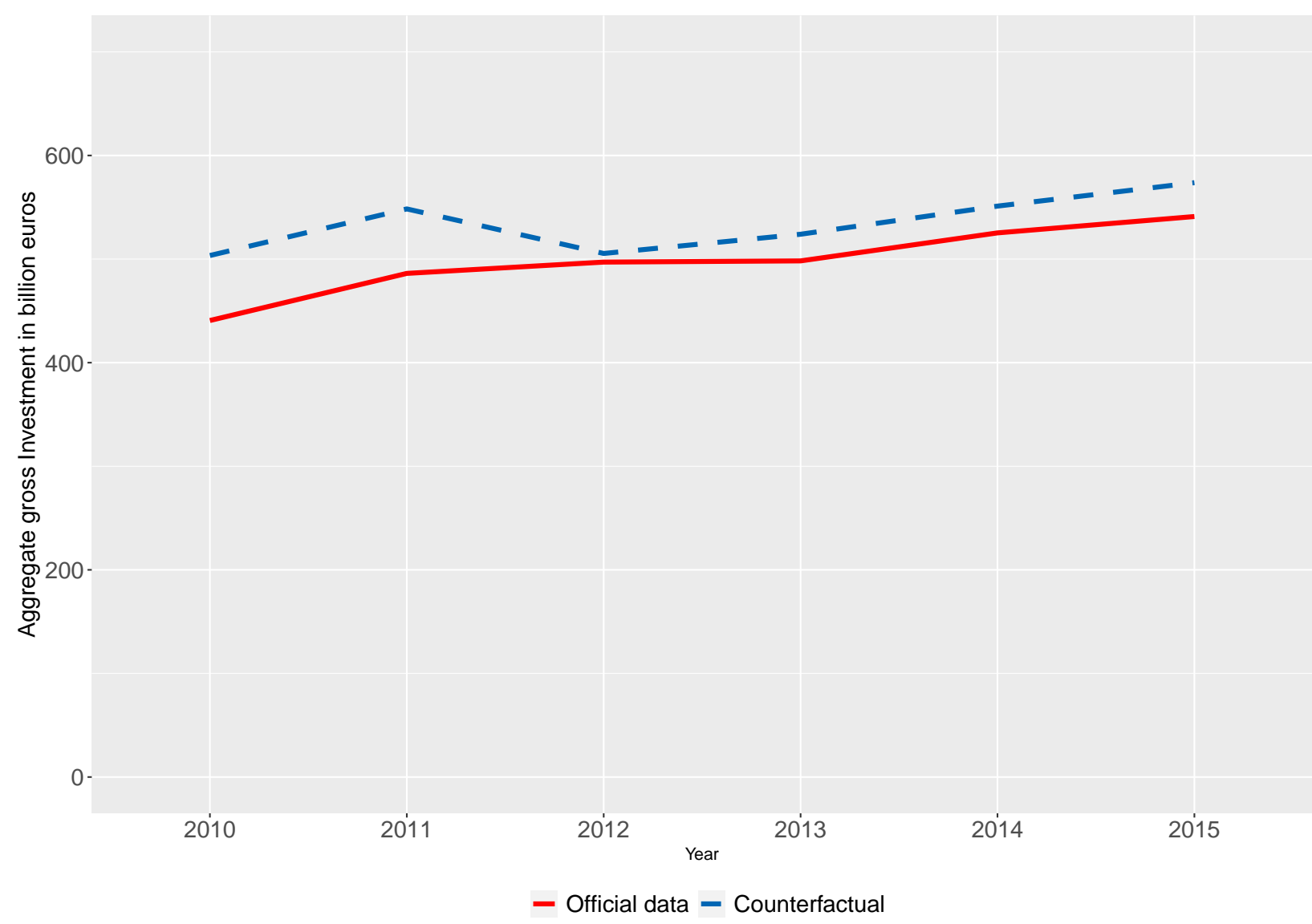

Note: The figure shows the time official times series for Germany's aggregate gross investment from the federal office of statistics (red, solid line) and the counterfactual aggregate investment series (blue, dashed line) implied by the absence of crowding out. See subsection 7.1 for details. 
Table 1: Summary Statistics of Main Variables

\begin{tabular}{lccc}
\hline \hline Statistic & $\mathrm{N}$ & Mean & St. Dev. \\
\hline Local Public Bank Spread & $5,600,816$ & 0.0071 & 0.0086 \\
Investment Rate & $2,470,268$ & 0.1511 & 0.8417 \\
Interest Rate & 233,433 & 0.1075 & 0.1147 \\
Bank Liabilities Growth & 269,471 & 0.1664 & 0.9778 \\
Cashflow Share & 550,543 & 0.0944 & 0.1483 \\
Firm Size & $4,167,569$ & 6.0420 & 1.9451 \\
Sales Growth & 847,770 & 0.0729 & 0.2830 \\
Equity Ratio & $4,084,037$ & 0.4036 & 0.3360 \\
Employment & $2,165,117$ & 28.2831 & 63.1735 \\
Age & $9,124,290$ & 17.7486 & 19.6768 \\
\hline
\end{tabular}

Note: The table shows the numbers of observation, the mean and the standard deviation of the main variables and controls. Data are annual, sample period is 2010-2016. 
Table 2: Firm lending rates and municipal lending shares

\begin{tabular}{|c|c|c|c|c|}
\hline \multirow[b]{3}{*}{$\Lambda$} & \multicolumn{4}{|c|}{ Dependent variable: Firm Interest Rate } \\
\hline & \multicolumn{2}{|c|}{ savings banks } & \multicolumn{2}{|c|}{ cooperative banks } \\
\hline & $\begin{array}{c}1.866^{* * *} \\
(0.377)\end{array}$ & $\begin{array}{c}1.734^{* * *} \\
(0.482)\end{array}$ & $\begin{array}{c}-1.278 \\
(0.993)\end{array}$ & $\begin{array}{l}-1.203 \\
(1.003)\end{array}$ \\
\hline$\Lambda \times$ Municipal Spread & $\begin{array}{c}-0.838^{* * *} \\
(0.203)\end{array}$ & $\begin{array}{c}-0.620^{* *} \\
(0.293)\end{array}$ & $\begin{array}{c}-0.502 \\
(0.767)\end{array}$ & $\begin{array}{c}0.187 \\
(0.813)\end{array}$ \\
\hline Tier1 regulatory capital ratio & & $\begin{array}{c}0.013^{* *} \\
(0.006)\end{array}$ & & $\begin{array}{c}0.001 \\
(0.003)\end{array}$ \\
\hline County FE & Yes & Yes & Yes & Yes \\
\hline Time FE & Yes & Yes & Yes & Yes \\
\hline Clustered SE & County & County & County & County \\
\hline Observations & 2,849 & 6,603 & 1,960 & 4,883 \\
\hline $\mathrm{R}^{2}$ & 0.901 & 0.792 & 0.906 & 0.791 \\
\hline
\end{tabular}

Note: The table shows the results from the bank-level panel regressions run separately for the sample of Sparkassen (columns 1 and 2) and Volksbanken (columns 3 and 4)

$$
i_{t}^{F, b}=\mathbf{a} \times \Lambda_{t}^{b}+\mathbf{b} \times \Lambda_{t}^{b} \times \operatorname{Municipal} \operatorname{Spread}_{t}+\boldsymbol{\beta}^{\prime} \boldsymbol{X}_{\boldsymbol{t}}^{\boldsymbol{b}}+\boldsymbol{\delta}_{t}^{b}+u_{t}^{b}
$$

where $i_{t}^{F, b}$ and $\Lambda_{t}^{b}$ are the average firm lending rate and the public (municipal) debt share of a banks' total lending of bank $b$ in year $t$ respectively. MuniCIPAL SPREAD $t$ is the spread of municipal borrowing rates over deposit rates. The vector $\boldsymbol{X}_{t}^{f}$ contains Tier 1 regulatory capital ratio as time-varying bank-specific control. The vector $\boldsymbol{\delta}_{t}^{f}$ collects countyand time- fixed effects. Standard errors are clustered by county and presented in parentheses. Data are annual, sample period is $2010-2016 .{ }^{*} \mathrm{p}<0.1$; $^{* *} \mathrm{p}<0.05$; $^{* * *} \mathrm{p}<0.01$ 
Table 3: Firm-level investment-Baseline results

\begin{tabular}{|c|c|c|c|c|c|}
\hline & \multicolumn{4}{|c|}{ Dependent variable: Investment Rate } & \multirow[b]{2}{*}{ (5) } \\
\hline & (1) & (2) & (3) & (4) & \\
\hline $\mathcal{S P K}$ & $\begin{array}{c}-1.317^{* * *} \\
(0.410)\end{array}$ & $\begin{array}{c}-1.047^{* * *} \\
(0.368)\end{array}$ & $\begin{array}{c}-0.883^{* *} \\
(0.367)\end{array}$ & $\begin{array}{c}-0.822^{* *} \\
(0.369)\end{array}$ & $\begin{array}{c}-0.881^{* *} \\
(0.371)\end{array}$ \\
\hline $\mathcal{S P K} \times \eta$ & $\begin{array}{c}1.968^{* * *} \\
(0.251)\end{array}$ & $\begin{array}{c}1.392^{* * *} \\
(0.185)\end{array}$ & $\begin{array}{c}1.364^{* * *} \\
(0.185)\end{array}$ & $\begin{array}{c}1.307^{* * *} \\
(0.187)\end{array}$ & $\begin{array}{c}1.345^{* * *} \\
(0.193)\end{array}$ \\
\hline Firm size & & $\begin{array}{c}-0.368^{* * *} \\
(0.021)\end{array}$ & $\begin{array}{c}-0.369^{* * *} \\
(0.021)\end{array}$ & $\begin{array}{c}-0.370^{* * *} \\
(0.022)\end{array}$ & $\begin{array}{c}-0.368^{* * *} \\
(0.022)\end{array}$ \\
\hline Equity share & & $\begin{array}{c}0.331^{* * *} \\
(0.032)\end{array}$ & $\begin{array}{c}0.331^{* * *} \\
(0.032)\end{array}$ & $\begin{array}{c}0.332^{* * *} \\
(0.031)\end{array}$ & $\begin{array}{c}0.327^{* * *} \\
(0.032)\end{array}$ \\
\hline Firm FE & Yes & Yes & Yes & Yes & Yes \\
\hline Time FE & Yes & Yes & No & No & No \\
\hline County-Time FE & No & No & Yes & Yes & No \\
\hline Sector-Time FE & No & No & No & Yes & No \\
\hline County-Sector-Time FE & No & No & No & No & Yes \\
\hline Clustered SE & County-Sector & County-Sector & County-Sector & County-Sector & County-Sector \\
\hline Observations & $1,886,235$ & $1,865,386$ & $1,865,386$ & $1,865,386$ & $1,865,386$ \\
\hline $\mathrm{R}^{2}$ & 0.356 & 0.372 & 0.372 & 0.373 & 0.417 \\
\hline
\end{tabular}

Note: The table shows the results from the firm-level panel regression

$$
\mathrm{INV}_{t}^{f}=\alpha \times \mathcal{S P} \mathcal{K}_{t}^{f}+\beta \times \boldsymbol{\eta}^{f} \times \mathcal{S P} \mathcal{K}_{t}^{f}+\boldsymbol{\beta}^{\prime} \boldsymbol{X}_{\boldsymbol{t}}^{\boldsymbol{f}}+\boldsymbol{\delta}_{t}^{f}+u_{t}^{f},
$$

where $\operatorname{INV}_{t}^{f}$ and $\mathcal{S P \mathcal { K }} \mathcal{K}_{t}^{f}$ are the investment rate and the local bank spread of firm $f$ in year $t$ respectively. $\boldsymbol{\eta}^{f}$ is the firm's substitution elasticity, which is measured by firm's total assets size. The vector $\boldsymbol{X}_{t}^{f}$ contains equity share and firm size as time-varying firm-specific controls. The vector $\boldsymbol{\delta}_{t}^{f}$ collects a range of fixed effects, including firm fixed effects, time fixed effects, county-time, sector-time and/or county-sector-time fixed effects. Standard errors are clustered by county and sector and presented in parentheses. Data are annual, sample period is $2010-2016 .{ }^{*} \mathrm{p}<0.1 ;{ }^{* *} \mathrm{p}<0.05$; $* * * \mathrm{p}<0.01$ 
Table 4: Firm-level investment-results with different measures of substitution elasticities $\boldsymbol{\eta}$

\begin{tabular}{|c|c|c|c|c|}
\hline & \multicolumn{4}{|c|}{ Dependent variable: Investment Rate } \\
\hline & Firm size & Employment & Age & Number of banks \\
\hline & (1) & (2) & (3) & (4) \\
\hline $\mathcal{S P K}$ & $\begin{array}{c}-0.881^{* *} \\
(0.371)\end{array}$ & $\begin{array}{c}-3.480^{* * *} \\
(0.822)\end{array}$ & $\begin{array}{c}-0.925^{* *} \\
(0.363)\end{array}$ & $\begin{array}{c}-1.598^{* * *} \\
(0.496)\end{array}$ \\
\hline $\mathcal{S P K} \times \eta$ & $\begin{array}{c}1.345^{* * *} \\
(0.193)\end{array}$ & $\begin{array}{c}3.158^{* * *} \\
(0.357)\end{array}$ & $\begin{array}{c}0.058^{* * *} \\
(0.012)\end{array}$ & $\begin{array}{c}1.488^{* * *} \\
(0.331)\end{array}$ \\
\hline$\eta$ & & & & $\begin{array}{c}-0.023^{* * *} \\
\quad(0.003)\end{array}$ \\
\hline Firm size & $\begin{array}{c}-0.368^{* * *} \\
(0.022)\end{array}$ & $\begin{array}{c}-0.310^{* * *} \\
(0.024)\end{array}$ & $\begin{array}{c}-0.371^{* * *} \\
(0.022)\end{array}$ & $\begin{array}{c}-0.371^{* * *} \\
(0.022)\end{array}$ \\
\hline Equity share & $\begin{array}{c}0.327^{* * *} \\
(0.032)\end{array}$ & $\begin{array}{c}0.305^{* * *} \\
(0.035)\end{array}$ & $\begin{array}{c}0.329^{* * *} \\
(0.033)\end{array}$ & $\begin{array}{c}0.329^{* * *} \\
(0.033)\end{array}$ \\
\hline Firm FE & Yes & Yes & Yes & Yes \\
\hline County-Sector-Time FE & Yes & Yes & Yes & Yes \\
\hline Clustered SE & County-Sector & County-Sector & County-Sector & County-Sector \\
\hline Observations & $1,865,386$ & 420,716 & $1,916,405$ & $1,916,405$ \\
\hline $\mathrm{R}^{2}$ & 0.417 & 0.520 & 0.422 & 0.422 \\
\hline
\end{tabular}

Note: The table shows the results from the firm-level panel regression

$$
\mathrm{INV}_{t}^{f}=\alpha \times \mathcal{S P} \mathcal{K}_{t}^{f}+\beta \times \boldsymbol{\eta}^{f} \times \mathcal{S} \mathcal{P} \mathcal{K}_{t}^{f}+\boldsymbol{\beta}^{\prime} \boldsymbol{X}_{t}^{f}+\boldsymbol{\delta}_{t}^{f}+u_{t}^{f},
$$

where $\operatorname{INV}_{t}^{f}$ and $\mathcal{S} \mathcal{P} \mathcal{K}_{t}^{f}$ are the investment rate and the local bank spread of firm $f$ in year $t$ respectively. $\boldsymbol{\eta}^{f}$ is the firm's substitution elasticity, which measure is defined in the column headings. The vector $\boldsymbol{X}_{t}^{f}$ contains equity share and firm size as time-varying firm-specific controls. The vector $\boldsymbol{\delta}_{t}^{f}$ includes firm fixed effects and county-sector-time fixed effects. Standard errors are clustered by county and sector and presented in parentheses. Data are annual, sample period is $2010-2016 .{ }^{*} \mathrm{p}<0.1 ;{ }^{* *} \mathrm{p}<0.05$; ${ }^{* * *} \mathrm{p}<0.01$ 
Table 5: Firm-level evidence on bank lending and interest rate

\begin{tabular}{lcc}
\hline \hline & \multicolumn{2}{c}{ Dependent variable: } \\
\cline { 2 - 3 } & Bank Liability Growth & Interest Rate \\
\hline $\mathcal{S P \mathcal { K }}$ & $-6.701^{* *}$ & 0.243 \\
& $(2.960)$ & $(0.195)$ \\
$\mathcal{S P \mathcal { K }} \times \eta$ & $2.186^{*}$ & $-0.132^{* * *}$ \\
& $(1.140)$ & $(0.045)$ \\
& & \\
Firm size & $-0.649^{* * *}$ & 0.0001 \\
& $(0.034)$ & $(0.001)$ \\
Equity share & $2.317^{* * *}$ & $-0.057^{* * *}$ \\
& $(0.132)$ & $(0.005)$ \\
\hline Firm FE & & Yes \\
County-Sector-Time FE & Yes & Yes \\
Clustered SE & Yes & County-Sector \\
Observations & County-Sector & 180,817 \\
\hline \hline
\end{tabular}

Note: The table shows the results from the firm-level panel regression

$$
Y_{t}^{f}=\alpha \times \mathcal{S} \mathcal{P} \mathcal{K}_{t}^{f}+\beta \times \boldsymbol{\eta}^{f} \times \mathcal{S} \mathcal{P} \mathcal{K}_{t}^{f}+\boldsymbol{\beta}^{\prime} \boldsymbol{X}_{t}^{f}+\boldsymbol{\delta}_{t}^{f}+u_{t}^{f},
$$

where $\mathrm{Y}_{t}^{f}=\left[\right.$ BANK LIABILITy GROWTH $_{t}^{f}$, INTEREST RATE $\left.{ }_{t}^{f}\right] . S P K_{t}^{f}$ is the local bank spread of firm $f$ in year $t . \boldsymbol{\eta}^{f}$ is the firm's substitution elasticity, which is measured by firm's total assets size. The vector $\boldsymbol{X}_{t}^{f}$ contains equity share and firm size as time-varying firm-specific controls. The vector $\boldsymbol{\delta}_{t}^{f}$ includes firm fixed effects and county-sector-time fixed effects. Standard errors are clustered by county and sector and presented in parentheses. Data are annual, sample period is $2010-2016 .{ }^{*} \mathrm{p}<0.1 ;{ }^{* *} \mathrm{p}<0.05 ;{ }^{* * *} \mathrm{p}<0.01$ 


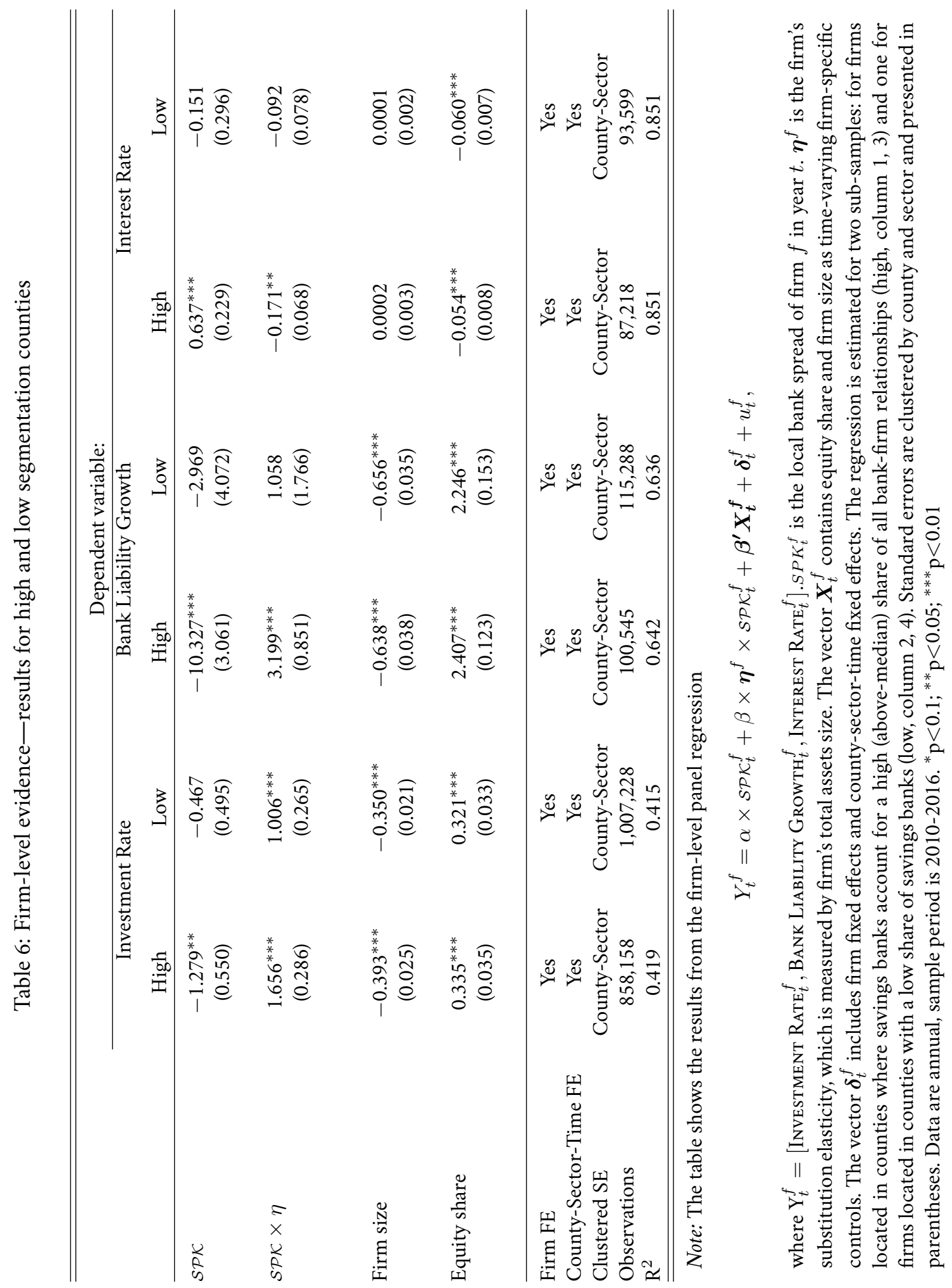


Table 7: Firm-level evidence based on granular IV

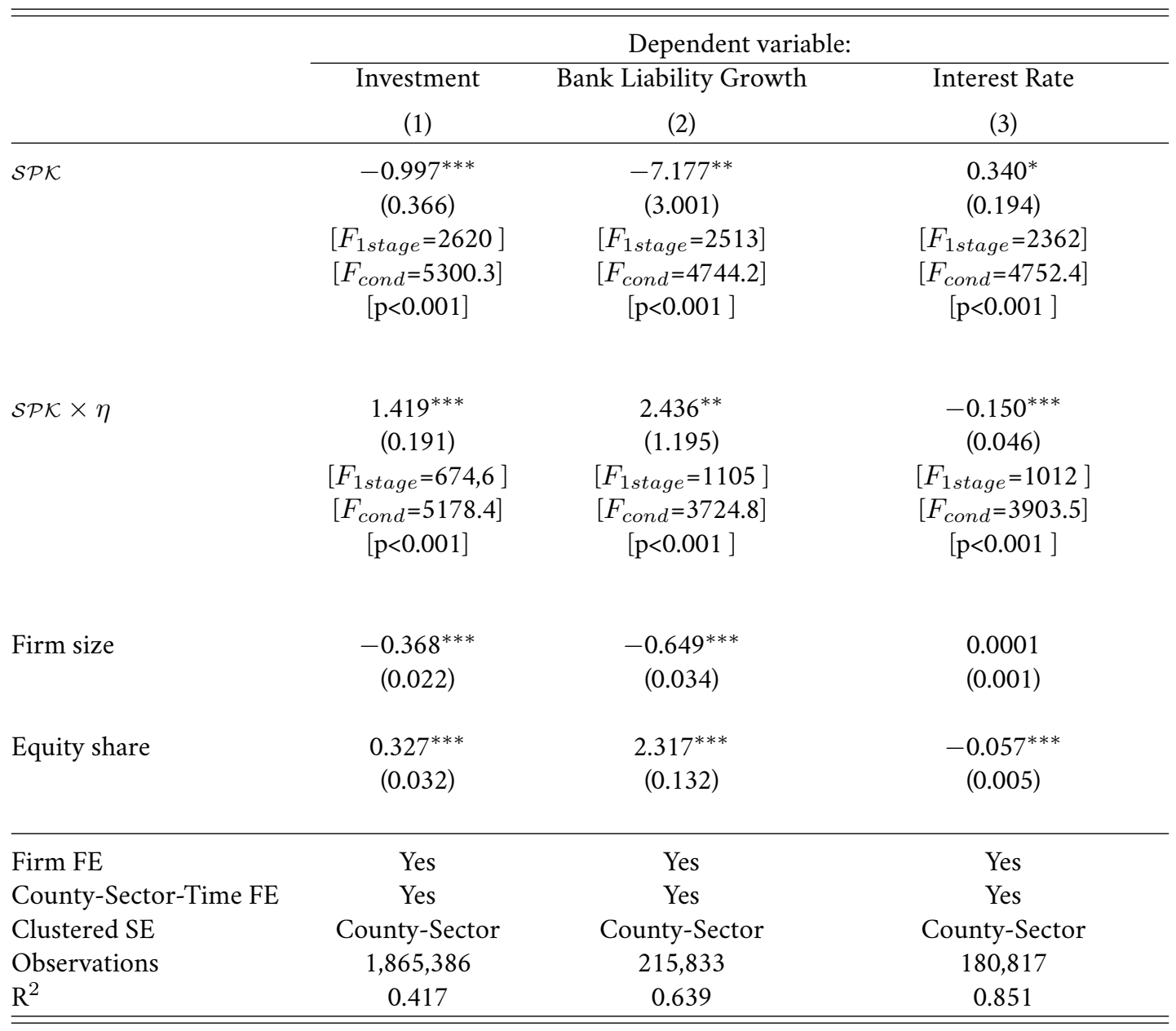

Note: The table shows the results of the second stage from the firm-level panel IV regression

$$
Y_{t}^{f}=\alpha \times \widehat{\widehat{S P \mathcal{K}} t_{t}^{f}}+\beta \times \boldsymbol{\eta}^{f} \widehat{\times \mathcal{S P}} \mathcal{K}_{t}^{f}+\boldsymbol{\beta}^{\prime} \boldsymbol{X}_{t}^{f}+\boldsymbol{\delta}_{t}^{f}+u_{t}^{f},
$$

where $\mathrm{Y}_{t}^{f}=\left[\operatorname{INV}_{t}^{f}\right.$, BANK LIABILITY Growth ${ }_{t}^{f}$, INTEREST RATE $\left.{ }_{t}^{f}\right] \widehat{\mathcal{S P K}_{t}^{f}}$ and $\boldsymbol{\eta}^{f} \widehat{\times \mathcal{S P} \mathcal{K}_{t}^{f}}$ are instrumented using the granular instrumental variable (GIV) defined in equation (10). See section 5.4 for details. $\mathcal{S P} \mathcal{K}_{t}^{f}$ is the local bank spread of firm $f$ in year $t . \boldsymbol{\eta}^{f}$ is the firm's substitution elasticity, which is measured by firm's total assets size. The vector $\boldsymbol{X}_{t}^{f}$ contains equity share and firm size as time-varying firm-specific controls. The vector $\boldsymbol{\delta}_{t}^{f}$ includes firm fixed effects and county-sector-time fixed effects. Standard errors are clustered by county and sector and presented in parentheses. Statistics in squared brackets pertain to the first-stage regressions: $F_{1 \text { stage }}$ denotes the F-statistic from the first stage. $F_{\text {cond }}$ is the tests for weak identification based on the conditional F-statistics by Sanderson and Windmeijer (2016). The associated p-values are bootstrapped and reported below $F_{\text {cond }}$. Data are annual, sample period is $2010-2016 .{ }^{*} \mathrm{p}<0.1 ;{ }^{* *} \mathrm{p}<0.05 ;{ }^{* * *} \mathrm{p}<0.01$ 
Table 8: Banks' municipal lending shares and local public debt

\begin{tabular}{|c|c|}
\hline & Dependent variable: Bank's municipal lending share, $\lambda$ \\
\hline Local Public Debt in 2010 & $\begin{array}{c}0.087^{* * *} \\
(0.022)\end{array}$ \\
\hline Local Public Debt in $2010 \times$ FP & $\begin{array}{c}-6.700^{* *} \\
(2.633)\end{array}$ \\
\hline SPK-Dummy $\times$ Local Public Debt in 2010 & $\begin{array}{c}0.108 \\
(0.092)\end{array}$ \\
\hline SPK-Dummy $\times$ LocalPublicDebT in $2010 \times$ FP & $\begin{array}{c}31.296^{* *} \\
(12.406)\end{array}$ \\
\hline SPK-DumMY $\times$ FP & $\begin{array}{l}-1.384 \\
(1.042)\end{array}$ \\
\hline SPK-DuмmY & $\begin{array}{c}0.037^{* * *} \\
(0.003)\end{array}$ \\
\hline $\begin{array}{l}\text { County-Time FE } \\
\text { Clustered SE } \\
\text { Observations } \\
\mathrm{R}^{2}\end{array}$ & $\begin{array}{c}\text { Yes } \\
\text { County } \\
9,335 \\
0.504\end{array}$ \\
\hline
\end{tabular}

Note: The table shows the results from the bank-level panel regression

$$
\begin{aligned}
\lambda_{t}^{b}= & \gamma \times \operatorname{Local} \operatorname{LublicDebT}_{2010}^{c}(b)+\delta \times \operatorname{Local} \operatorname{PublicDebT}_{2010}^{c}(b) \times \mathrm{FP}_{t}^{s(b)} \\
& +\phi \mathbb{1}_{b} \times \operatorname{LocalPublicDebT}_{2010}^{c}(b)+\rho \mathbb{1}_{b} \times \operatorname{LocalPublicDebT}_{2010}^{c}(b) \times \mathrm{FP}_{t}^{s(b)} \\
& +\psi \mathbb{1}_{b} \times \mathrm{FP}_{t}^{s(b)}+\kappa \mathbb{1}_{b}+\operatorname{CoNTROLS}_{t}^{b}+\nu_{t}^{b}
\end{aligned}
$$

where $\lambda_{t}^{b}$ is the public debt share on local bank b's balance sheet, $\mathrm{FP}_{t}^{s(b)}$ is the pressure for fiscal consolidation in state $s(b)$ in which bank $b$ is located and LocalPublicDeвt ${ }_{2010}^{c}(b)$ is the ratio of outstanding local public debt to local GDP in municipality (county) $c(b)$, at the beginning of the sample period (2010) and $\mathbb{1}_{b}$ is an indicator dummy that is one if bank $b$ is a savings bank. ConTrols contains bank controls as well as state- and time fixed effects. Standard errors are clustered by county and presented in parentheses. Data are annual, sample period is 2010-2016. * $\mathrm{p}<0.1$; ${ }^{* *} \mathrm{p}<0.05 ;{ }^{* * *} \mathrm{p}<0.01$ 
Table 9: Firm lending rates and municipal lending shares-local fiscal pressure as IV

\begin{tabular}{|c|c|c|}
\hline & \multicolumn{2}{|c|}{ Firm Interest Rate } \\
\hline & savings banks & cooperative banks \\
\hline$\Lambda(f i t)$ & $\begin{array}{c}1.085 \\
(1.080) \\
{\left[F_{1 \text { stage }}=10.87\right]} \\
{\left[F_{\text {cond }}=22.24\right]} \\
{[\mathrm{p}<0.001]}\end{array}$ & $\begin{array}{c}-0.483 \\
(4.243) \\
{\left[F_{1 \text { stage }}=5.85\right]} \\
{\left[F_{\text {cond }}=11.91\right]} \\
{[\mathrm{p}<0.01]}\end{array}$ \\
\hline$\Lambda \times$ Municipal Spread (fit) & $\begin{array}{c}-1.456^{* *} \\
(0.0 .679) \\
{\left[F_{1 \text { stage }}=11.54\right]} \\
{\left[F_{\text {cond }}=23.95\right]} \\
{[\mathrm{p}<0.001]}\end{array}$ & $\begin{array}{c}-0.613 \\
(4.042) \\
{\left[F_{1 \text { stage }}=5.67\right]} \\
{\left[F_{\text {cond }}=11.61\right]} \\
{[\mathrm{p}<0.01]}\end{array}$ \\
\hline Deposit share & $\begin{array}{c}-1.718^{* * *} \\
(0.645)\end{array}$ & $\begin{array}{c}-1.817^{* *} \\
(0.784)\end{array}$ \\
\hline (log) Total assets & $\begin{array}{c}-0.060^{* * *} \\
(0.018)\end{array}$ & $\begin{array}{c}-0.099^{* * *} \\
(0.015)\end{array}$ \\
\hline $\begin{array}{l}\text { State-Time FE } \\
\text { Clustered SE } \\
\text { Observations } \\
R^{2}\end{array}$ & $\begin{array}{c}\text { Yes } \\
\text { County } \\
2,742 \\
0.828\end{array}$ & $\begin{array}{c}\text { Yes } \\
\text { County } \\
6,514 \\
0.735\end{array}$ \\
\hline
\end{tabular}

Note: The table shows results of panel IV regressions of banks' average firm lending rates on their municipal lending shares of the form

$$
i_{t}^{F, b}=\mathbf{a} \times \widehat{\Lambda_{t}^{b}}+\mathbf{b} \times\left[\Lambda_{t}^{b} \times \widehat{\operatorname{MuNICIPAL}} \operatorname{SpREAD}_{t}\right]+\boldsymbol{\beta}^{\prime} \boldsymbol{X}_{\boldsymbol{t}}^{\boldsymbol{b}}+\boldsymbol{\delta}_{t}^{b}+u_{t}^{b}
$$

for local savings banks (left column) and local cooperative banks (right column). Here, $i_{t}^{F, b}$ is the average firm lending rate of bank $b$ in year $t . \Lambda_{t}^{b}=\frac{1}{1-\lambda}$, where $\lambda$ is the public (municipal) debt share of a banks' total lending and Municipal SPREAD $t$ is the spread of municipal borrowing rates over deposit rates. The vector $\boldsymbol{X}_{t}^{f}$ contains deposit share and total assets as time-varying bank-specific control. The vector $\boldsymbol{\delta}_{t}^{f}$ collects state-time fixed effects. Standard errors are clustered by county and provided in parentheses. The left column reports results for local public banks, the right column for local cooperative banks. Both regressions use local fiscal pressure $\left(\operatorname{LFP}_{t}^{b}\right)$ as defined in equation (13) and its interaction with the municipal spread as instruments. Statistics in squared brackets pertain to the firststage regressions: $F_{1 \text { stage }}$ denotes the F-statistic from the first stage. $F_{\text {cond }}$ is the tests for weak identification based on the conditional F-statistics by Sanderson and Windmeijer (2016). The associated p-values are bootstrapped and reported below $F_{\text {cond }}$. Data are annual, sample period is 2010-2016. ${ }^{*} \mathrm{p}<0.1{ }^{* *} \mathrm{p}<0.05 ;{ }^{* * *} \mathrm{p}<0.01$. 
Table 10: Firm-level evidence with austerity-induced $\mathcal{S P K}$

\begin{tabular}{|c|c|c|c|}
\hline & \multicolumn{3}{|c|}{ Dependent variable: } \\
\hline & $\begin{array}{c}\text { Investment } \\
(1) \\
\end{array}$ & $\begin{array}{c}\text { Bank Liability Growth } \\
\text { (2) } \\
\end{array}$ & $\begin{array}{c}\text { Interest Rate } \\
(3) \\
\end{array}$ \\
\hline $\mathcal{S P K}$ & $\begin{array}{c}-0.635^{* * *} \\
(0.195)\end{array}$ & $\begin{array}{c}-3.505^{* * *} \\
(1.311)\end{array}$ & $\begin{array}{c}0.203^{* *} \\
(0.089)\end{array}$ \\
\hline $\mathcal{S P K} \times \eta$ & $\begin{array}{c}0.820^{* * *} \\
(0.087)\end{array}$ & $\begin{array}{l}1.264^{* *} \\
(0.532)\end{array}$ & $\begin{array}{c}-0.076^{* * *} \\
(0.024)\end{array}$ \\
\hline Firm size & $\begin{array}{c}-0.368^{* * *} \\
(0.022)\end{array}$ & $\begin{array}{c}-0.649^{* * *} \\
(0.034)\end{array}$ & $\begin{array}{l}0.0002 \\
(0.001)\end{array}$ \\
\hline Equity share & $\begin{array}{c}0.327^{* * *} \\
(0.032)\end{array}$ & $\begin{array}{c}2.317^{* * *} \\
(0.132)\end{array}$ & $\begin{array}{c}-0.057^{* * *} \\
(0.005)\end{array}$ \\
\hline Firm FE & Yes & Yes & Yes \\
\hline County-Sector-Time FE & Yes & Yes & Yes \\
\hline Clustered SE & County-Sector & County-Sector & County-Sector \\
\hline Observations & $1,865,386$ & 215,833 & 180,817 \\
\hline $\mathrm{R}^{2}$ & 0.417 & 0.639 & 0.851 \\
\hline
\end{tabular}

Note: The table shows the results from the firm-level panel regression

$$
Y_{t}^{f}=\alpha \times \mathcal{S P} \mathcal{K}^{A, f_{t}}+\beta \times \boldsymbol{\eta}^{f} \times \mathcal{S P} \mathcal{K}^{A, f_{t}}+\boldsymbol{\beta}^{\prime} \boldsymbol{X}_{\boldsymbol{t}}^{\boldsymbol{f}}+\boldsymbol{\delta}_{t}^{f}+u_{t}^{f},
$$

where $\mathrm{Y}_{t}^{f}=\left[\operatorname{INV}_{t}^{f}\right.$, BANK LIABILITY Growth $t_{t}^{f}$, INTEREST RATE $\left.{ }_{t}^{f}\right] . S P K^{A, f_{t}}$ is the austerity induced component of local public bank spread of firm $f$ in year $t$ that we obtained from the IV regression presented in Table 9. $\boldsymbol{\eta}^{f}$ is the firm's substitution elasticity, which is measured by firm's total assets size. The vector $\boldsymbol{X}_{t}^{f}$ contains equity share and firm size as time-varying firm-specific controls. The vector $\boldsymbol{\delta}_{t}^{f}$ includes firm fixed effects and county-sector-time fixed effects. Standard errors are clustered by county and sector and presented in parentheses. Data are annual, sample period is 2010-2016. ${ }^{*} \mathrm{p}<0.1 ;{ }^{* *} \mathrm{p}<0.05 ;{ }^{* * *} \mathrm{p}<0.01$ 


\section{A Appendix: Theoretical framework}

We consider a stylized model based on Brunnermeier and Koby (2020) which we extend to include a statutory requirement for the local public banks to engage in public (municipal) lending. Banks engage in public lending to local municipalities or in private lending to local firms. The bank's problem is to maximize its equity $E_{1}$ in the next period:

$$
E_{1}=\left(1+i^{F}\right) F+\left(1+i^{P}\right) P-\left(1+i^{D}\right) D
$$

where $F$ is private lending to firms, $P$ is public (municipal) lending and $D$ are deposits and $i^{F}, i^{P}$ and $i^{D}$ the associated interest rates. The bank's decision is subject to the balance sheet identity

$$
F+P=D+E_{0}
$$

and initial equity, $E_{0}$, is exogenous. The bank also faces a capital constraint

$$
\bar{\psi} \leqq \frac{E_{0}}{F}=: \psi
$$

in which municipal lending $\mathrm{P}$ has a risk weight of zero.

Local public banks (savings banks) differ from local cooperative banks because they face a statutory requirement to engage in lending to the local public sector. We formalize this requirement in the simplest possible manner as a lower bound $\bar{\lambda}$ on the fraction of its balance sheet that the savings bank has to invest into public lending:

$$
\bar{\lambda} \leqq \frac{P}{F+P}=: \lambda
$$

We call this the statutory public lending constraint. It arises from the bank's specific statutory mandate and/or from the direct political control of municipalities over the local public banks.

Importantly, we assume that banks have market power in their lending market. Firms' loan demand function $F$ is downward sloping in $i_{F}$, so that $F^{\prime}=d F / d i^{F}<0$. We also assume that there is market power in deposit markets, with deposit supply upward sloping in $i_{D}$, so that $D^{\prime}=d D / d i^{D}>0$. The interest rate on public loans, $i_{P}$, is exogenous and the bank chooses the optimal $\mathrm{P}$ subject to its statutory constraint.

With these assumptions we can write the Lagrangian as

$$
\begin{aligned}
\mathcal{L}= & \left(1+i^{F}\right) F+\left(1+i^{P}\right) P-\left(1+i^{D}\right) D-\mu\left(F+P-D-E_{0}\right) \\
& -\chi\left(\psi F-E_{0}\right)-\theta((\bar{\lambda}-1) P+\bar{\lambda} F)
\end{aligned}
$$


which leads to the following first-order conditions:

$$
\begin{aligned}
& \frac{\partial \mathcal{L}}{\partial i^{F}}=F+\left(1+i^{F}\right) F^{\prime}-\mu F^{\prime}-\chi \psi F^{\prime}-\theta \bar{\lambda} F^{\prime}=0 \\
& \frac{\partial \mathcal{L}}{\partial i^{D}}=-D-\left(1+i^{D}\right) D^{\prime}+\mu D^{\prime}=0 \Longleftrightarrow \mu=\frac{D}{D^{\prime}}+\left(1+i^{D}\right) \\
& \frac{\partial \mathcal{L}}{\partial P}=\left(1+i^{P}\right)-\mu+\theta(1-\bar{\lambda})=0 \Longleftrightarrow \mu=\left(1+i^{P}\right)+\theta(1-\bar{\lambda})
\end{aligned}
$$

Rearranging yields the following solutions for lending and deposit rates:

$$
\begin{aligned}
& i^{F}=i^{P}-\frac{1}{\varepsilon_{F}}+\chi \psi+\theta \\
& i^{D}=i^{P}-\frac{1}{\varepsilon_{D}}+\theta(1-\bar{\lambda})
\end{aligned}
$$

where we have used the abbreviations $\varepsilon_{F}=\frac{F^{\prime}}{F}<0$ and $\varepsilon_{D}=\frac{D^{\prime}}{D}>0$ for the (semi-) elasticities of loan demand and deposit supply w.r.t the respective interest rate.

As is apparent from (A.8), the bank will charge higher interest rates to its firm customers whenever the statutory public lending constraint is binding $(\theta>0)$. A binding statutory public lending constraint will also induce the bank to try to lengthen its balance sheet by raising additional deposits. To this end, as can be seen from the third term on the right hand side of equation (A.9), the bank will increase its deposit rate. By attracting additional deposits, it can partially undo the reduction in profitable firm-lending that is imposed by the public lending constraint.

Rearranging equation (A.9), we obtain

$$
\theta=\frac{\frac{1}{\varepsilon_{D}}-\left(i^{P}-i^{D}\right)}{1-\bar{\lambda}}
$$

We refer to $\theta$ as the 'break-even' spread since it reflects the increase in the interest rate that the bank will charge firms to at least partially make up for the opportunity cost of having a part of its balance sheet being tied up in relatively low-yielding municipal lending (as compared to firm lending). The break-even spread decreases in the municipal bond spread $i^{P}-i^{D}$ and increases when the statutory constraint tightens due to an exogenous increase in $\bar{\lambda}$.

We can also see from the first term in the denominator of equation (A.10) how balance sheet constraints affect the the break-even spread. A given increase in the lower bound $\bar{\lambda}$ on municipal lending will ceteris paribus have a higher marginal impact on the break-even spread if the bank has a very inelastic balance sheet, i.e. if the deposit supply elasticity $\varepsilon_{D}$ is low. The intuition is that for low-elasticity banks it is costly to increase $\lambda$ by raising additional funds so that a large part of the increase in $\lambda$ will have to come from a reduction of firm lending. This means that there is a stronger rivalry between firm and municipal lending so that the opportunity costs of municipal lending is higher. We empirically explore the role of balance sheet elasticity below. 
From theory to empirical specification Plugging (A.10) into (A.8), we get the solution for the firm lending rate that is the basis for the empirical estimation of the break-even spread in regression (4) in the main body of the paper:

$$
i^{F}=\underbrace{i^{P}-\frac{1}{\varepsilon_{F}}+\chi \psi}_{i_{t}^{U}}+\underbrace{\frac{\frac{1}{\varepsilon_{D}}}{1-\bar{\lambda}}}_{\mathbf{a} \times \Lambda_{t}^{b}} \underbrace{-\frac{\left(i^{P}-i^{D}\right)}{1-\bar{\lambda}}}_{\mathbf{b} \times \Lambda_{t}^{b} \times \text { MUNICIPAL SPREAD } t}
$$

Importantly, for constrained banks, an increase in the lower bound $\bar{\lambda}$ will also increase the observed levels of $\lambda$. At the same time, a decline in the spread between public sector borrowing and deposit rates, $i^{P}-i^{D}$ will increase the break-even spread and thus the firm-lending rate and it does so more strongly for banks with high shares of public debt on their books. This is what our empirical specification in (4) captures.

Note that in our model, the bank's deposit rate is a decision variable and its optimal values will differ across banks, depending e.g. on the parameters $\varepsilon_{D}$ and $\varepsilon_{F}$ and on $\bar{\lambda}$. Our empirical implementation in (4) uses the municipal spread defined as the difference between the municipal bond rate and the average deposit rate across all German banks. Focusing on this common component across all banks allows us to isolate the exogenous part of the decline in the difference $i^{P}-i^{D}$.

Exploring balance sheet elasticity To explore the role of balance sheet elasticity, as captured by $\varepsilon_{D}$, we split the sample of savings banks into two, depending on the banks deposit dependence as captured by the deposit-loan ratio. We associate banks with high (low) deposit dependence with a low (high) balance sheet elasticity. Deposits are typically a very stable funding base but it is also relatively hard to attract additional deposit funding as compared to e.g. wholesale funding. In Table B.5 we re-run our bank-level regressions (4) on the two sub-samples. We find that the coefficient $\mathbf{a}$ on the stand-alone term $\Lambda$, which according to the model should correspond to $1 / \varepsilon_{D}$, is higher for the deposit-dependent savings banks. Hence, in line with our conjecture, deposit-dependent banks have less elastic balance sheets overall.

Conversely, for deposit-dependent (low-elasticity) banks the coefficient b on the interaction $\Lambda \times$ MUNICIPAL SPREAD $t$ is somewhat less precisely estimated (though not significantly different from minus unity). By contrast, for banks with high elasticity, the point estimate remains very close to negative unity and highly significant. Again this is consistent with the predictions of the model. Banks that have considerable market power in their local deposit markets have relatively more leeway to set deposit rates independently, while refinancing rates of high-elasticity banks are likely to comove more strongly with the country-wide market rates that we use in our regressions here. 


\section{Appendix B. Additional tables and results}

Table B.1: Firm-level evidence-results with placebo $\mathcal{S P K}$

\begin{tabular}{lccc}
\hline \hline & \multicolumn{3}{c}{ Dependent variable: } \\
\cline { 2 - 4 } & Investment & Bank Liability Growth & Interest Rate \\
& $(1)$ & $(2)$ & $(3)$ \\
\hline $\mathcal{S P \mathcal { N }}$ placebo & -0.409 & 1.161 & -0.063 \\
& $(0.510)$ & $(2.313)$ & $(0.206)$ \\
$\mathcal{S P \mathcal { K }}$ placebo $\times \eta$ & & & -0.051 \\
& $1.190^{* * *}$ & 0.761 & $(0.084)$ \\
& $(0.296)$ & $(0.759)$ & \\
& & & \\
Firm size & & & -0.001 \\
& & & $(0.001)$ \\
Equity share & $-0.370^{* * *}$ & $-0.623^{* * *}$ & $-0.058^{* * *}$ \\
& $(0.022)$ & $(0.029)$ & $(0.005)$ \\
\hline Firm FE & $0.332^{* * *}$ & $2.263^{* * *}$ & Yes \\
County-Sector-Time FE & $(0.031)$ & $(0.101)$ & Yes \\
Clustered SE & & & County-Sector \\
Observations & Yes & Yes & 180,817 \\
$\mathrm{R}^{2}$ & County-Sector & County-Sector & 0.766 \\
\hline \hline
\end{tabular}

Note: The table shows the results from the firm-level panel regression

$$
Y_{t}^{f}=\alpha \times \mathcal{S P} \mathcal{K}_{\text {placebo }, t}^{f}+\beta \times \boldsymbol{\eta}^{f} \times \mathcal{S P} \mathcal{K}_{\text {placebo }, t}^{f}+\boldsymbol{\beta}^{\prime} \boldsymbol{X}_{t}^{f}+\boldsymbol{\delta}_{t}^{f}+u_{t}^{f},
$$

where $\mathrm{Y}_{t}^{f}=\left[\operatorname{INV}_{t}^{f}\right.$, BANK LiabiLiTy Growth ${ }_{t}^{f}$, INTEREST RATE $\left.{ }_{t}^{f}\right] . S P K_{\text {placebo, }}^{f}$ is the placebo local bank spread of firm $f$ in year $t$ that was constructed for the local cooperative banks as in Table 2 column 3. $\boldsymbol{\eta}^{f}$ is the firm's substitution elasticity, which is measured by firm's total assets size. The vector $\boldsymbol{X}_{t}^{f}$ contains equity share and firm size as time-varying firm-specific controls. The vector $\boldsymbol{\delta}_{t}^{f}$ includes firm fixed effects and county-sector-time fixed effects. Standard errors are clustered by county and sector and presented in parentheses. Data are annual, sample period is $2010-2016 .{ }^{*} \mathrm{p}<0.1{ }^{* *} \mathrm{p}<0.05$; ${ }^{* * *} \mathrm{p}<0.01$ 
Table B.2: Firm-level investment—extended set of firm-specific controls

\begin{tabular}{|c|c|c|c|c|}
\hline & \multicolumn{4}{|c|}{ Dependent variable: Investment Rate } \\
\hline & $\begin{array}{c}\text { Firm size } \\
(1) \\
\end{array}$ & $\begin{array}{c}\text { Employment } \\
(2) \\
\end{array}$ & $\begin{array}{l}\text { Age } \\
(3) \\
\end{array}$ & $\begin{array}{c}\text { Number of banks } \\
\text { (4) }\end{array}$ \\
\hline $\mathcal{S P K}$ & $\begin{array}{c}-8.323^{* * *} \\
(1.684)\end{array}$ & $\begin{array}{c}-6.301^{* * *} \\
(1.765)\end{array}$ & $\begin{array}{c}-4.492^{* * *} \\
(1.226)\end{array}$ & $\begin{array}{c}-5.595^{* * *} \\
(1.145)\end{array}$ \\
\hline $\mathcal{S P \mathcal { K }} \times \eta$ & $\begin{array}{c}2.572^{* * *} \\
(0.659)\end{array}$ & $\begin{array}{c}2.285^{* * *} \\
(0.664)\end{array}$ & $\begin{array}{c}0.080^{* * *} \\
(0.022)\end{array}$ & $\begin{array}{c}2.027^{* * *} \\
(0.472)\end{array}$ \\
\hline$\eta$ & & & & $\begin{array}{c}-0.033^{* * *} \\
(0.007)\end{array}$ \\
\hline Firm size & $\begin{array}{c}-0.394^{* * *} \\
(0.030)\end{array}$ & $\begin{array}{c}-0.283^{* * *} \\
(0.030)\end{array}$ & $\begin{array}{c}-0.399^{* * *} \\
(0.030)\end{array}$ & $\begin{array}{c}-0.399^{* * *} \\
(0.030)\end{array}$ \\
\hline Equity share & $\begin{array}{c}0.201^{* * *} \\
(0.043)\end{array}$ & $\begin{array}{c}0.234^{* * *} \\
(0.056)\end{array}$ & $\begin{array}{c}0.191^{* * *} \\
(0.040)\end{array}$ & $\begin{array}{c}0.190^{* * *} \\
(0.040)\end{array}$ \\
\hline Cashflow share & $\begin{array}{c}0.303^{* * *} \\
(0.050)\end{array}$ & $\begin{array}{c}0.260^{* * *} \\
(0.042)\end{array}$ & $\begin{array}{c}0.286^{* * *} \\
(0.050)\end{array}$ & $\begin{array}{c}0.286^{* * *} \\
(0.050)\end{array}$ \\
\hline Revenue growth & $\begin{array}{c}0.159^{* * *} \\
(0.018)\end{array}$ & $\begin{array}{c}0.184^{* * *} \\
(0.026)\end{array}$ & $\begin{array}{c}0.160^{* * *} \\
(0.018)\end{array}$ & $\begin{array}{c}0.160^{* * *} \\
(0.018)\end{array}$ \\
\hline Firm FE & Yes & Yes & Yes & Yes \\
\hline County-Sector-Time FE & Yes & Yes & Yes & Yes \\
\hline Clustered SE & County-Sector & County-Sector & County-Sector & County-Sector \\
\hline Observations & 180,199 & 103,675 & 186,930 & 186,930 \\
\hline $\mathrm{R}^{2}$ & 0.672 & 0.636 & 0.676 & 0.676 \\
\hline
\end{tabular}

Note: The table shows the results from the firm-level panel regression

$$
\mathrm{INV}_{t}^{f}=\alpha \times \mathcal{S P} \mathcal{K}_{t}^{f}+\beta \times \boldsymbol{\eta}^{f} \times \mathcal{S P} \mathcal{K}_{t}^{f}+\boldsymbol{\beta}^{\prime} \boldsymbol{X}_{\boldsymbol{t}}^{\boldsymbol{f}}+\boldsymbol{\delta}_{t}^{f}+u_{t}^{f},
$$

where $\operatorname{INV}_{t}^{f}$ and $\mathcal{S P} \mathcal{K}_{t}^{f}$ are the investment rate and the local bank spread of firm $f$ in year $t$ respectively. $\boldsymbol{\eta}^{f}$ is the firm's substitution elasticity, which measure is defined in the column headings. The vector $\boldsymbol{X}_{t}^{f}$ contains equity share, firm size, cashflow share and revenue growth as time-varying firm-specific controls. The vector $\boldsymbol{\delta}_{t}^{f}$ includes firm fixed effects and county-sector-time fixed effects. Standard errors are clustered by county and sector and presented in parentheses. Data are annual, sample period is $2010-2016 .{ }^{*} \mathrm{p}<0.1 ;{ }^{* *} \mathrm{p}<0.05 ;{ }^{* * *} \mathrm{p}<0.01$ 


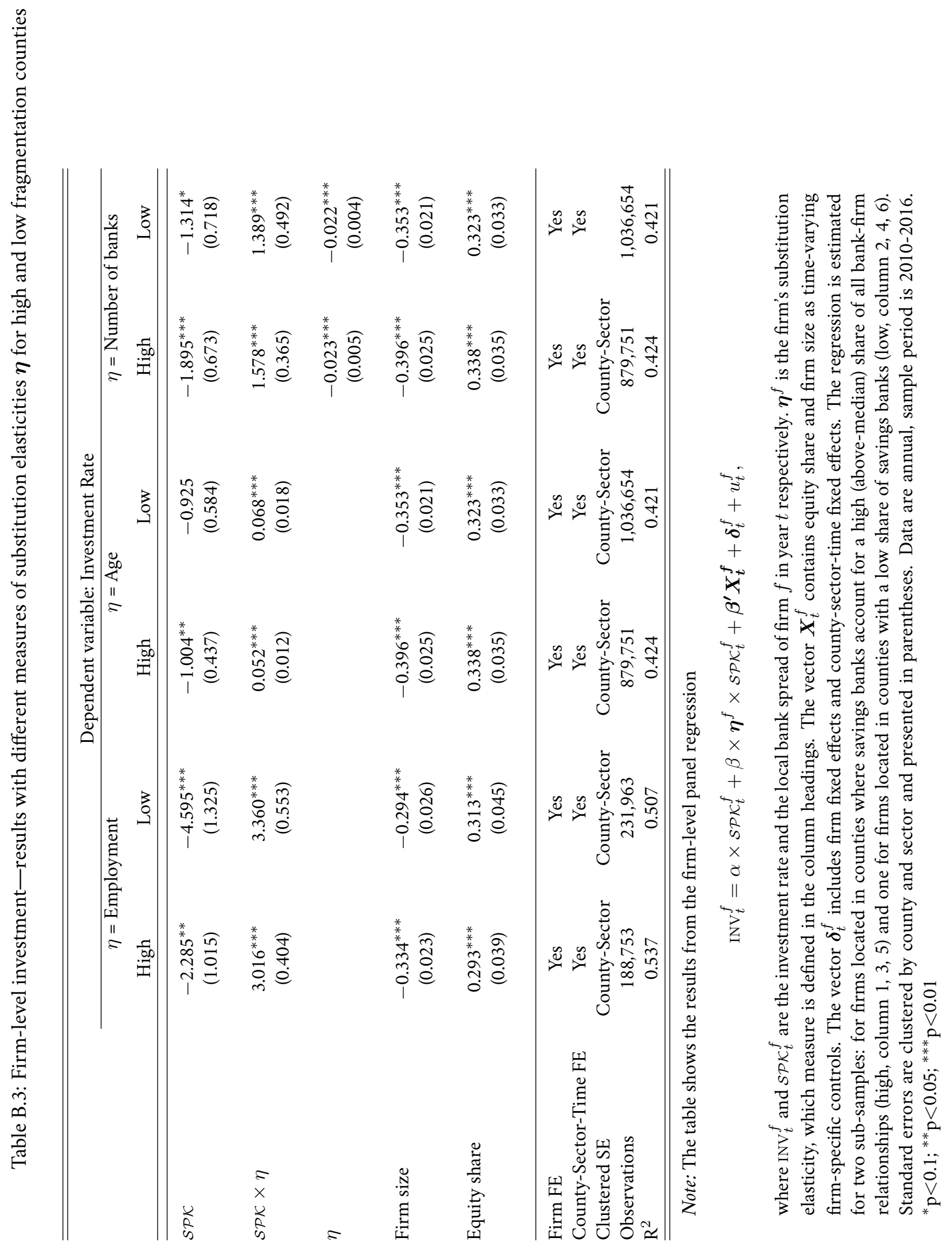




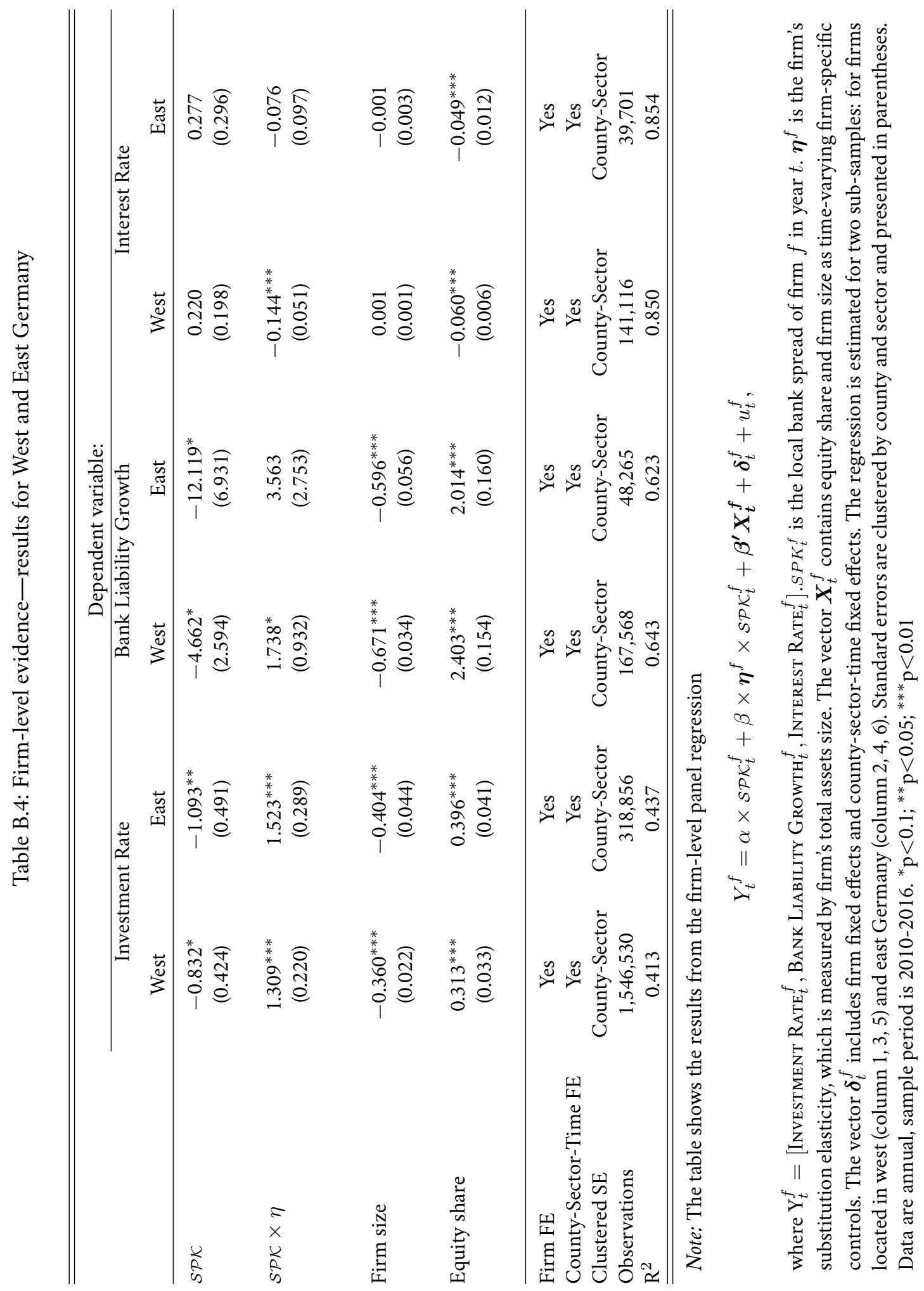


Table B.5: Firm lending rates and municipal lending shares—results for high and low deposit-dependent savings banks

\begin{tabular}{|c|c|c|c|c|}
\hline \multirow[b]{3}{*}{$\Lambda$} & \multicolumn{4}{|c|}{ Dependent variable: Firm Interest Rate } \\
\hline & \multicolumn{2}{|c|}{ high deposit-to-loans share } & \multicolumn{2}{|c|}{ low deposit-to-loans share } \\
\hline & $\begin{array}{c}1.917^{* * *} \\
(0.487)\end{array}$ & $\begin{array}{c}1.968^{* * *} \\
(0.578)\end{array}$ & $\begin{array}{l}1.288^{*} \\
(0.710)\end{array}$ & $\begin{array}{c}1.070 \\
(0.857)\end{array}$ \\
\hline$\Lambda \times$ Municipal Spread & $\begin{array}{c}-0.592^{* *} \\
(0.269)\end{array}$ & $\begin{array}{l}-0.473 \\
(0.332)\end{array}$ & $\begin{array}{c}-1.150^{* * *} \\
(0.261)\end{array}$ & $\begin{array}{c}-0.952^{* *} \\
(0.367)\end{array}$ \\
\hline Tier1 Regulatory Capital Ratio & & $\begin{array}{c}0.009 \\
(0.007)\end{array}$ & & $\begin{array}{c}0.015 \\
(0.010)\end{array}$ \\
\hline County FE & Yes & Yes & Yes & Yes \\
\hline Time FE & Yes & Yes & Yes & Yes \\
\hline Clustered SE & Region & Region & Region & Region \\
\hline Observations & 1,420 & 981 & 1,424 & 974 \\
\hline $\mathrm{R}^{2}$ & 0.915 & 0.924 & 0.903 & 0.905 \\
\hline
\end{tabular}

Note: The table shows the results from the bank-level panel regressions run separately for the sample of of Sparkassen with above (high, columns 1 and 2) and below (low, columns 3 and 4) the median deposit-to-loans share

$$
i_{t}^{F, b}=\mathbf{a} \times \Lambda_{t}^{b}+\mathbf{b} \times \Lambda_{t}^{b} \times \operatorname{Municipal} \operatorname{Spread}_{t}+\boldsymbol{\beta}^{\prime} \boldsymbol{X}_{\boldsymbol{t}}^{\boldsymbol{b}}+\boldsymbol{\delta}_{t}^{b}+u_{t}^{b}
$$

where $i_{t}^{F, b}$ and $\Lambda_{t}^{b}$ are the average firm lending rate and the public (municipal) debt share of a banks' total lending of bank $b$ in year $t$ respectively. MUNICIPAL SPREAD $t$ is the spread of municipal borrowing rates over deposit rates. The vector $\boldsymbol{X}_{t}^{f}$ contains Tier 1 regulatory capital ratio as time-varying bank-specific control. The vector $\boldsymbol{\delta}_{t}^{f}$ collects countyand time- fixed effects. Standard errors are clustered by county and presented in parentheses. Data are annual, sample period is $2010-2016 .{ }^{*} \mathrm{p}<0.1 ;{ }^{* *} \mathrm{p}<0.05 ;{ }^{* * *} \mathrm{p}<0.01$ 